\title{
The genus Dampiera (Goodeniaceae): systematic arrangement, nomenclatural notes and new taxa
}

\author{
M.T.M. Rajput ${ }^{1}$ and R.C. Carolin ${ }^{2}$
}

\begin{abstract}
Rajput, M.T.M., ${ }^{1}$ and Carolin, R.C. ${ }^{2}{ }^{1}$ Botany Dept, Sind University, Jamshoro, Pakistan; ${ }^{2} J o h n$ Ray Herbarium, University of Sydney, Australia 2006) 1988. The genus Dampiera (Goodeniaceae): systematic arrangement, nomenclatural notes and new taxa. Telopea 3(2): 183-216. - A cladistic analysis of the genus is presented with a discussion of the characters used and the results incorporated in a new subgeneric classification. A new subsection Angulares is proposed, the previous section Cephalantha is not recognized and the previous section Camptospora is reduced to the rank of series. Species and varieties in the genus Dampiera are provided with lectotypes and neotypes where required. Where there appears to be some doubt as to holotypes, these are discussed. The following new species are described: D. angulata, D. atriplicina, D. decurrens, D. deltoidea, D. fitzgeraldensis, D. fusca, D. galbraithiana, D. heteroptera, D. krauseana, D. obliqua, D. orchardii, D. pedunculata, D. ramosa, D. rodwayana, D. salahae, D. scaevolina, D. sylvestris and D. tephrea; D. dysantha (Benth.) and D. latealata (E. Pritzel) are raised to species rank.
\end{abstract}

\section{Introduction}

The genus Dampiera (Goodeniaceae) is confined to Australia and occurs throughout the continent in a wide variety of habitats. The genus contains 66 species as recognised at present. The last revision is due to Krause (1912). No previous assessment of phylogeny has been made.

The new taxa, nomenclatural changes and lectotypifications presented here, relate to the impending treatment of this genus in the 'Flora of Australia'. They are also necessary for a discussion of the systematics of the genus.

Both Bentham (1868) and Krause (1912) subdivided the genus into sections and although these systems were similar there were some minor differences principally in the level at which the subgeneric taxa were recognised and the emphasis which different characters were given. The results of Carolin (1959) and Rajput and Carolin (1984) suggest that a new assessment is necessary.

The most satisfactory subgeneric classification should be based upon the putative phylogeny of the genus. Cladistic methods in general are likely to provide a reasonable approximation to phylogeny although it is clear that they have some drawbacks (Carolin 1985; Johnson \& Briggs 1985) and that the algorithms may not in fact reproduce the correct phylogeny (Fiala \& Sokal 1985). Nevertheless, a cladogram obtained by parsimonious methods is a satisfactory starting point for considering possible phylogenies (Carolin 1986). The first section of this contribution attempts to develop a phylogeny in this way and provide a systematic framework for the genus.

The phylogeny and systematics are considered first because this section necessarily contains a discussion of the characters used in the descriptions of the new taxa. Some of these characters require special terminology, e.g. the hairs, and this is established before they are used. Moreover, the descriptions and nomenclatural notes are arranged in a systematic order and this is also established in the first section. 


\section{Phylogeny and systematic arrangement}

\section{Characters}

Whilst the characters which are used in a cladistic analysis are not usually weighted, it is clear that all cladograms are produced after the exclusion of characters which the researcher is prepared to reject (Carolin 1985, 1986). The method adopted here was to generate up to five parsimonious cladograms from characters which are considered to be important in discriminating between the species, using the WAGNER78 algorithm of Farris. This was quick and relatively cheap and in the earlier stages of this investigation the more sophisticated PAUP package was not available. This preliminary data set included 31 binary characters, some of which represented ordered multistate characters additively coded. However, a number of characters which discriminate effectively between species are exteremely homoplasic. That is they reverse more than three times on different branches or they reverse to the primitive condition and then revert to the advanced condition on the same branch. These appear to be relatively inconstant characters and may well obscure the phylogeny. Homoplasic characters may increase the number of most parsimonious trees which can be generated from a given set of data and may even decrease the probability of finding any of the most parsimonious trees. The characters which are herewith rejected as being too homoplasic to reflect phylogeny accurately are: (i) leaves dentate or entire; (ii) leaves lobed or entire; (iii) sepals present or absent; (iv) auriculate wing of the corolla smaller than the others or not.

A second data set, without these characters and containing 27 binary characters, some of which also were additive, was then used to generate other cladograms using Swofford's PAUP package (Swofford 1984). One hundred trees were generated using global branch swapping and a strict consensus tree was generated from them. Some further adjustment was then suggested.

To produce a cladogram it is necessary to polarize the states of a character and the most efficient way to do this is by outgroup comparison, although philosophically this may involve an infinite regress. Nevertheless, in this case there is a reasonably well authenticated higher level cladogram (Carolin 1977, Fig. 3) which identifies the clade within which Dampiera occurs and thus its sister groups, Anthotium plus Lechenaultia. It also suggests Brunonia as the sister clade to this one. Brunonia, however, shows a number of advanced characters and, if we accept Campanulaceae as the outgroup of the Goodeniaceae (see Carolin 1977), one can arrive at a most parsimonious solution for the primitive states of most characters using the methods of Maddison et al. (1984). Appendix 1 provides a quick reference to the characters used. Appendix 2 gives the data matrix used in the cladistic analysis.

Below are listed and discussed the characters which are used, together with the states which they may assume. The state coded ' 0 ' is considered to be primitive. Where this is not unequivocally determined by the outgroups some discussion is given. An asterisk $\left(^{*}\right)$ indicates that the immediate outgroups of Dampiera indicate the polarity of that character.

1. *Sub-shrub-0; rosette-1

2. *Sub-shrub-0; multicaulate-1

Multicaulate habit is defined as several more or less herbaceous stems arising from a very short stock. New growth starts more or less at ground level. 
Sometimes only one stem arises in any one year but over several years several stems arise. Sub-shrubs, on the other hand, have one or few basal woody stems which are usually much branched above and more or less long-lived. New growth starts on the branches of old growth. The lateral branches behave like the stems of the multicaulate plants. Indeed the multicaulate habit seems to have arisen as a condensation of the main stems of the sub shrubs into the thick basal stock with very short internodes (Fig. 1). The rosette habit represents a condensation of the lateral branches as well as the main stems.
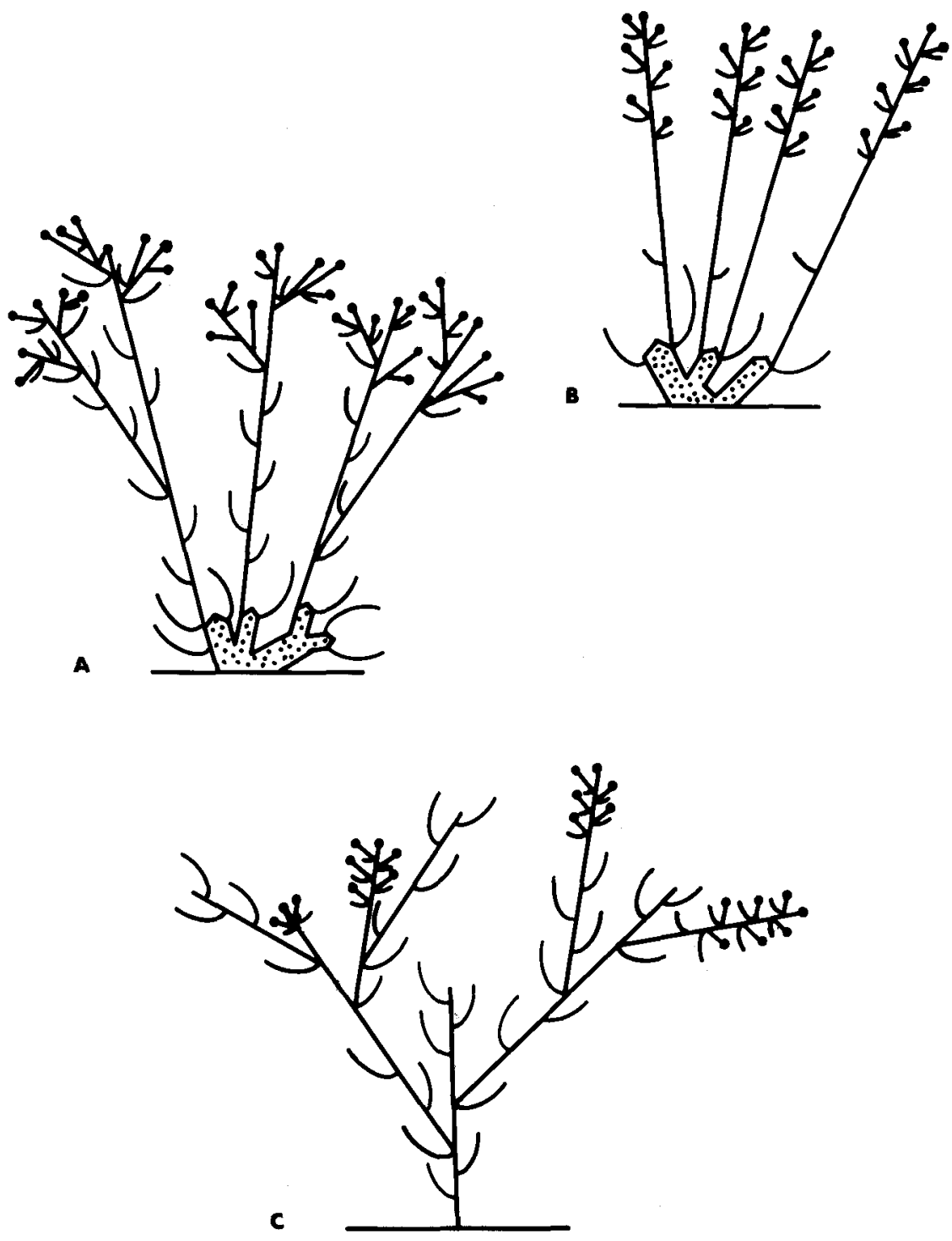

Fig. 1. Diagramatic representation of habit and inflorescence types as used in descriptions and in the cladistic analysis (see text for coding). A, multicaulate; panicles or clusters. B, rosette; thyrses, racemes, spikes or heads. C, subshrub; thyrses, racemes, spikes. 
3-6: Hair types (Fig. 2; see Carolin 1970). The standard for hair types used in this analysis is that found on the outside of the corolla. On other parts of the plant they tend to vary more. The evolution of hair types is not clear. Fig. 2 shows the various possibilities. Five cladograms were generated using all the possible sequences of hair-type evolution, together with all the other 27 characters. The sequence which gave the most parsimonious tree is that shown with solid lines. This was adopted for the final analysis.

$$
\text { I-0000; II-1000; III-0100; IV-0110; V-0111 }
$$

7. *Phyllotaxis: there are three main phyllotaxes found in the genus (Rajput \& Carolin 1984). Since the $1 / 2$ phyllotaxis is absolutely correlated with flat stems and it is considered to be at the end of a transformation series here, it is not separated from its precursor in the series, $1 / 3$ phyllotaxis.

$$
2 / 5 \text { or less }-0 ; 1 / 3 \& 1 / 2-1
$$

8-10. ${ }^{*}$ Stems: stems have been considered previously (Rajput \& Carolin 1984) and it has been shown that the stem type correlates with the internal anatomy. Only the morphological appearance of the stem is scored in this analysis.

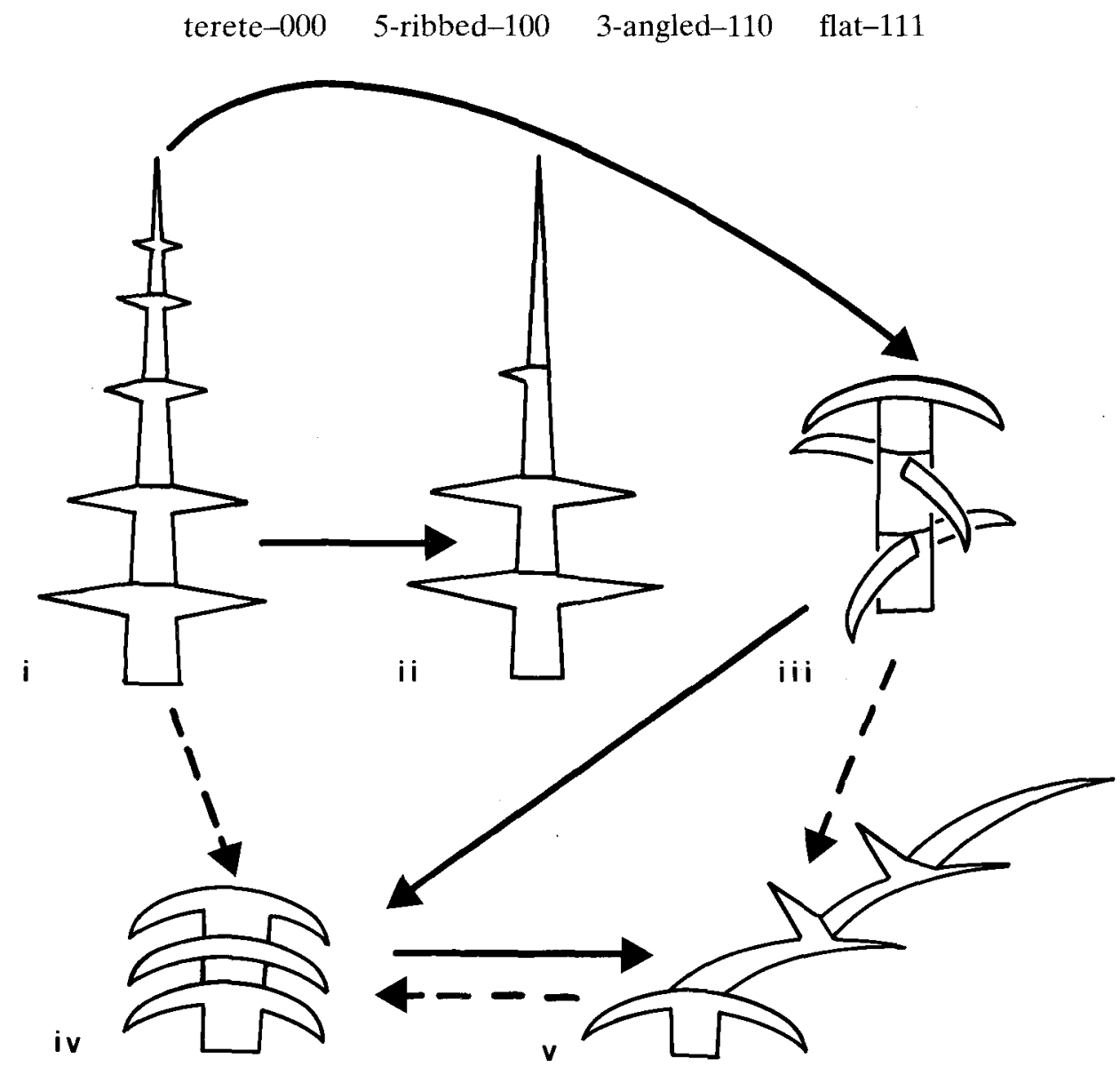

Fig. 2. Diagrammatic representation of hair types as used in the description and in the cladistic analysis (see text for coding). Broken lines represent possible phylogenetic connections; solid lines represent the phylogentic series adopted for the final analysis. 


\section{Leaves flat- -0 ; leaves revolute-1}

Although the outgroups of Dampiera have revolute leaves, the outgroups of the clade in which Dampiera occurs (Brunonia and Campanulaceae) clearly show, by the first doublet rule of Maddison et al. (1984), that flat leaves are primitive.

12. *Leaves cauline-0; leaves basal-1

13. *Leaves not in pseudowhorls-0; leaves tending to be in pseudowhorls-1

This describes the condition when the upper internodes of the main axis are reduced. The clustering of leaves in the axils is not included in the analysis.

14. Leaves \pm same size in inflorescence region-0; leaves reduced in inflorescence region-1.

The sister groups of Dampiera have bracts very reduced in size compared to the leaves. However, the sister clade of Dampiera and its allies indicates that the primitive inflorescences are cymes arising in the axils of the upper leaves (see Carolin 1967). The most parsimonious polarization is thus the one adopted here.

15. Leaves petiolate- 0 ; leaves sessile-1

The same argument applies here as to character 14.

16-18. *Hairs on mature leaves.

16. Glabrous -0 ; hairy on both surfaces-1

17. Hairy on both surfaces -0 ; glabrescent above-1

18. Hairy on either or both surfaces -0 ; glabrescent above and below-1

These three characters present a problem for polarization. Neither of the outgroups provides a satisfactory solution because, although simple and glandular hairs are found in the outgroups, these branched types of hairs are not found elsewhere in the family or in the Campanulaceae. Thus, the outgroups indicate that lack of any of these hair types on the leaves is primitive. This is accepted. However, when hairs do occur on the leaves in Dampiera, they are present on both surfaces in the young leaf. Moreover, in those species with both surfaces of the leaf glabrescent, the hairs disappear from the upper surface first. Using the generality criterion of Nelson (1978), the transformation series indicated in the coding is arrived at.

Many species are described as having glabrous leaves even when young. This is not strictly true since in all cases, except that of $D$. diversifolia the youngest leaves have at least a few hairs on both surfaces.

19-21. *Inflorescence. Since the inflorescence types are considered to represent a transformation series they are coded additively. Panicles or clusters are used to describe the situation illustrated by Carolin (1967, Fig. 6A). In many cases, however, more than one partial inflorescence appears to arise in the axil. This is due to the presence of a lateral branch which bears one or more partial inflorescences lateral to itself so near its base as to appear to occur in the axil of the main leaf (see Fig. 1).

000

panicles or clusters
110 thyrses racemes heads

111 thyrses racemes heads

22. *Sepals: present or absent-0; sepals replaced or surmounted by long hairs -1 
23. ${ }^{*}$ Corolla large (mostly $>5 \mathrm{~mm}$ long) -0 ; corolla small (mostly $<5 \mathrm{~mm}$ long) -1

24. *Ovary 2-locular-0; ovary 1-locular-1

25. *Ovary straight -0 ; ovary gibbous -1

26-27. *Ovule shape: a transformation series from staight through bent to Ushaped or horseshoe-shaped is indicated and the character is coded additively.

straight-00; bent-10; U-shaped or horseshoe-shaped-11

Table 1. Name codes used in Figs 3 and 4 and Appendix 2, showing the species represented by each code.

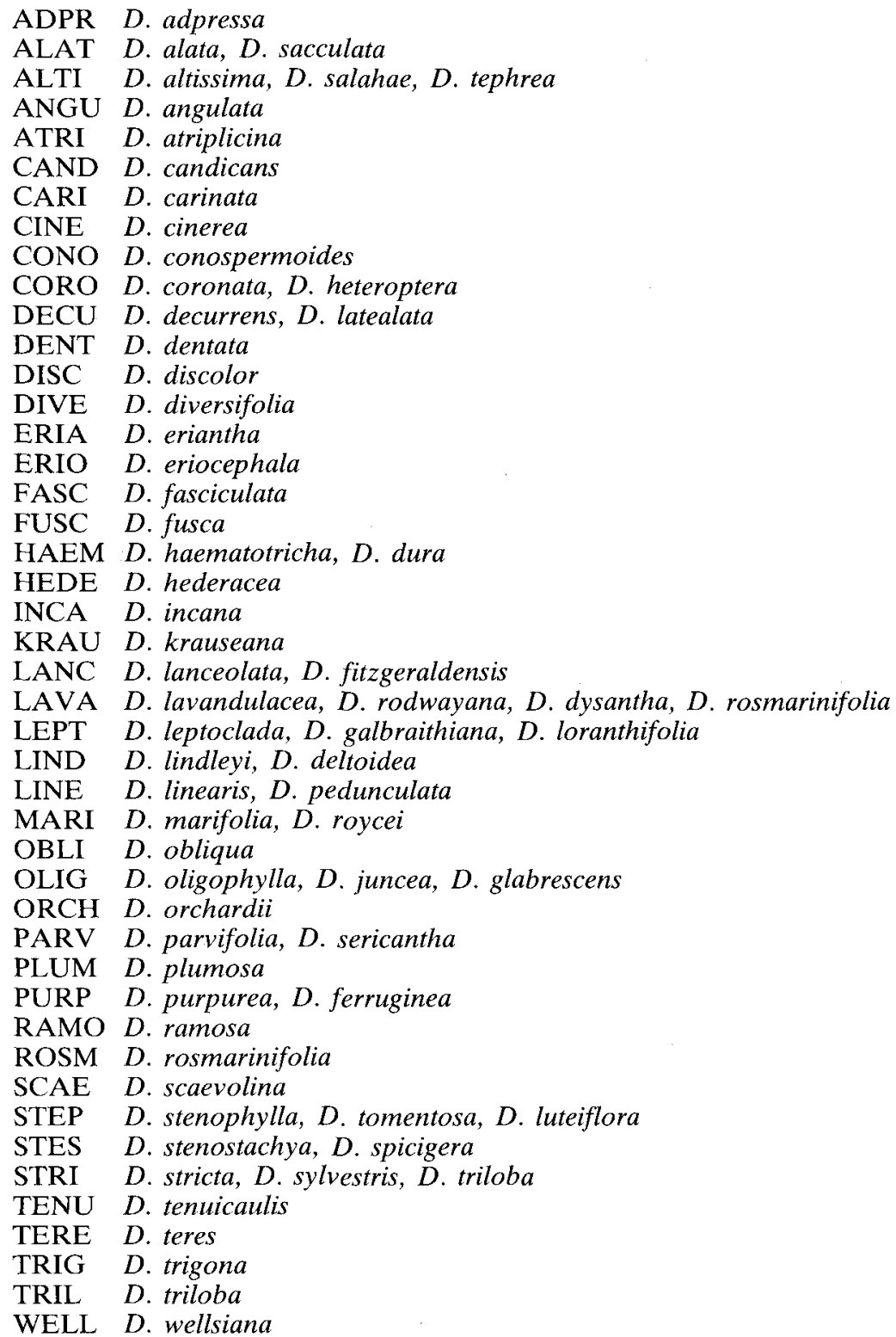




\section{Terminal taxa}

A number of species are omitted from appendix 2 and from the calculations and cladograms because they were either exactly the same as other species in terms of the characters used in the analysis or they were distinguished by only autapomorphies from one of the recognized clades. Where such species (or groups of species) form unresolved polychotomies with other terminal taxa, however, they have been included in Figs 3 and 4 . It is often not possible to resolve most of the terminal taxa containing several species because the characters which distinguish the constituent species cannot be satisfactorily polarized. Each terminal taxon, which thus may consist of several species, is identified by a four letter code. These codes, together with the species that they represent, are given in Table 1.

$D$. diversifolia is entirely glabrous and was included in the analysis omitting the characters on hair type.

\section{Results}

One of the trees generated is shown in Fig. 3 and the strict consensus tree is shown in Fig. 4. Most of the 100 trees which were generated represent rearrangements of the various polychotomies. None of them differed significantly from the one shown. The consensus tree indicates that homoplasies make resolution of the tree difficult without weighting characters. We would suggest that this can be done only in one case with any confidence. Giving extra importance to the small flowers of $D$. candicans and $D$. cinerea above their other characters resolves part of the polychotomy there (Fig. 5). No other species in the genus has such small flowers. D. ramosa, indeed, has smaller flowers than in most other species but they are still significantly larger than in $D$. candicans and $D$. cinerea. There is a significant anomaly in the reappearance of the bilocular ovary along the $D$. trigona-D. decurrens clade. Many workers would find this reversal unacceptable, arguing that the several independent morphogenetic events required to bring this about are unlikely to arise and reproduce the primitive condition. This is possible but at present undemonstrable. However, it is instructive to redraw the cladogram, in this case, bearing this in mind. If the whole clade above the ${ }^{*}$ on Fig. 4 is redrawn so that the most parsimonious solution is obtained whilst allowing for no reversal to the bilocular condition of the ovary, the result in Fig. 5 is obtained. This lengthens the tree by three steps. They are: characters 15 and 17 along the clade including subsect. Angulares and character 24 along the clade including sect. Linschotenia. Character 17 is 'mature leaves hairy on both surfaces; mature leaves glabrescent above'. Indeed, it is an additive precursor to character 18 which is 'mature leaves glabrescent above; mature leaves glabrescent on both surfaces'. The leaves of subsect. Angulares only have a few hairs on both surfaces in the very young stages and they are lost at more or less the same time on both surfaces, whereas the leaves of subsect. Dampiera are more densely hairy and lose the hairs first from the upper surface and then from the lower surface if they lose them at all.

The indication is that the state of 'mature leaves glabrescent on both surfaces' may not be strictly homologous in the two subsections. That is, in subsect. Angulares glabrescence on both surfaces is probably a single evolutionary change, whilst in subsect. Dampiera it probably arose separately by first the loss of hairs on the upper surface and then the loss of hairs on the lower surface. 


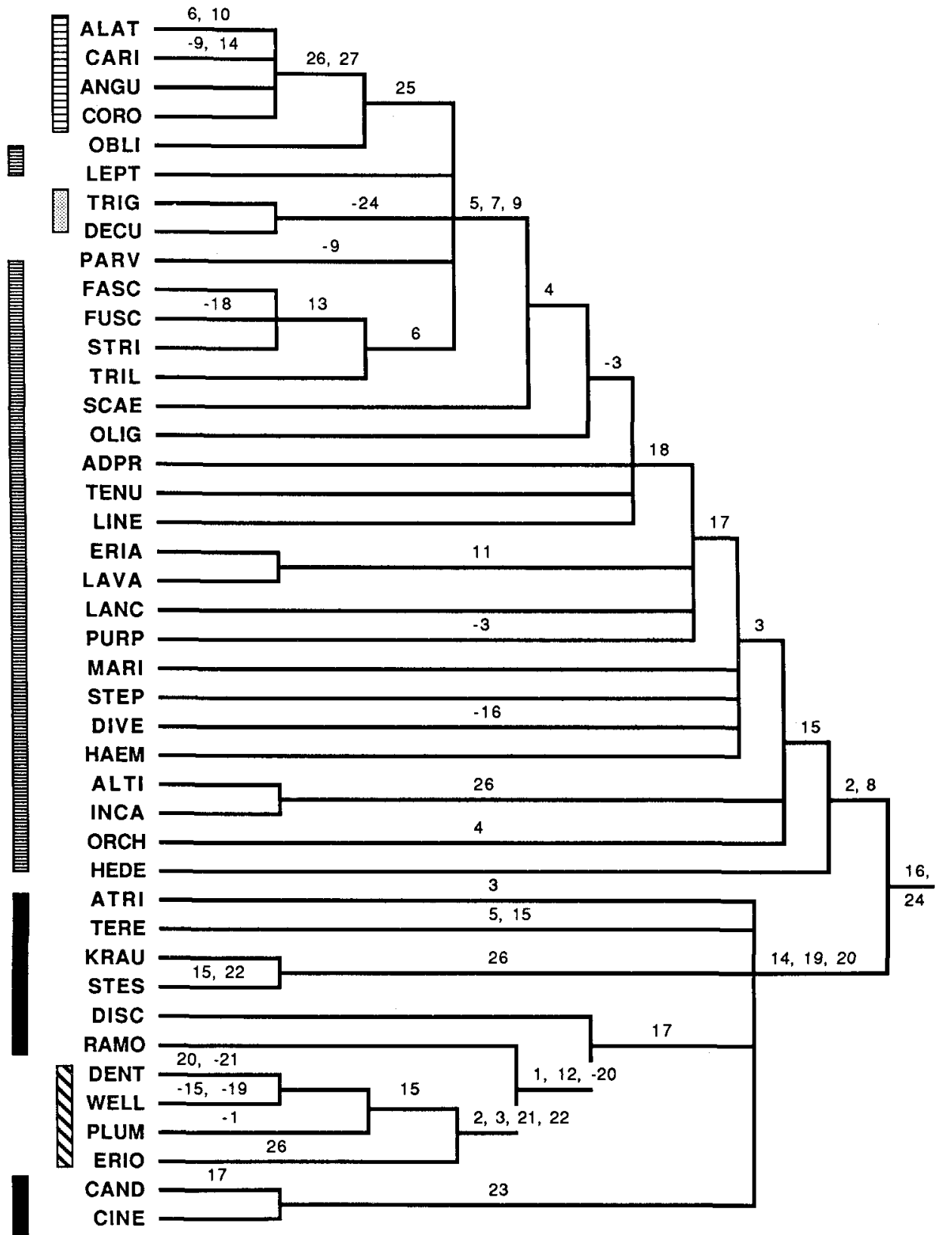

Fig. 3. One of the most parsimonious cladograms generated by PAUP (see Table 1 for key to codes of terminal taxa). Numbers indicate characters changing state from primitive to advanced, negative signs indicate reversals. Sections according to Bentham (1868) shown at top.

$\begin{array}{lll}\text { Camptospora } & \text { Dicoelia } \\ \text { (Eu)Dampiera } & \text { Linschotenia }\end{array}$




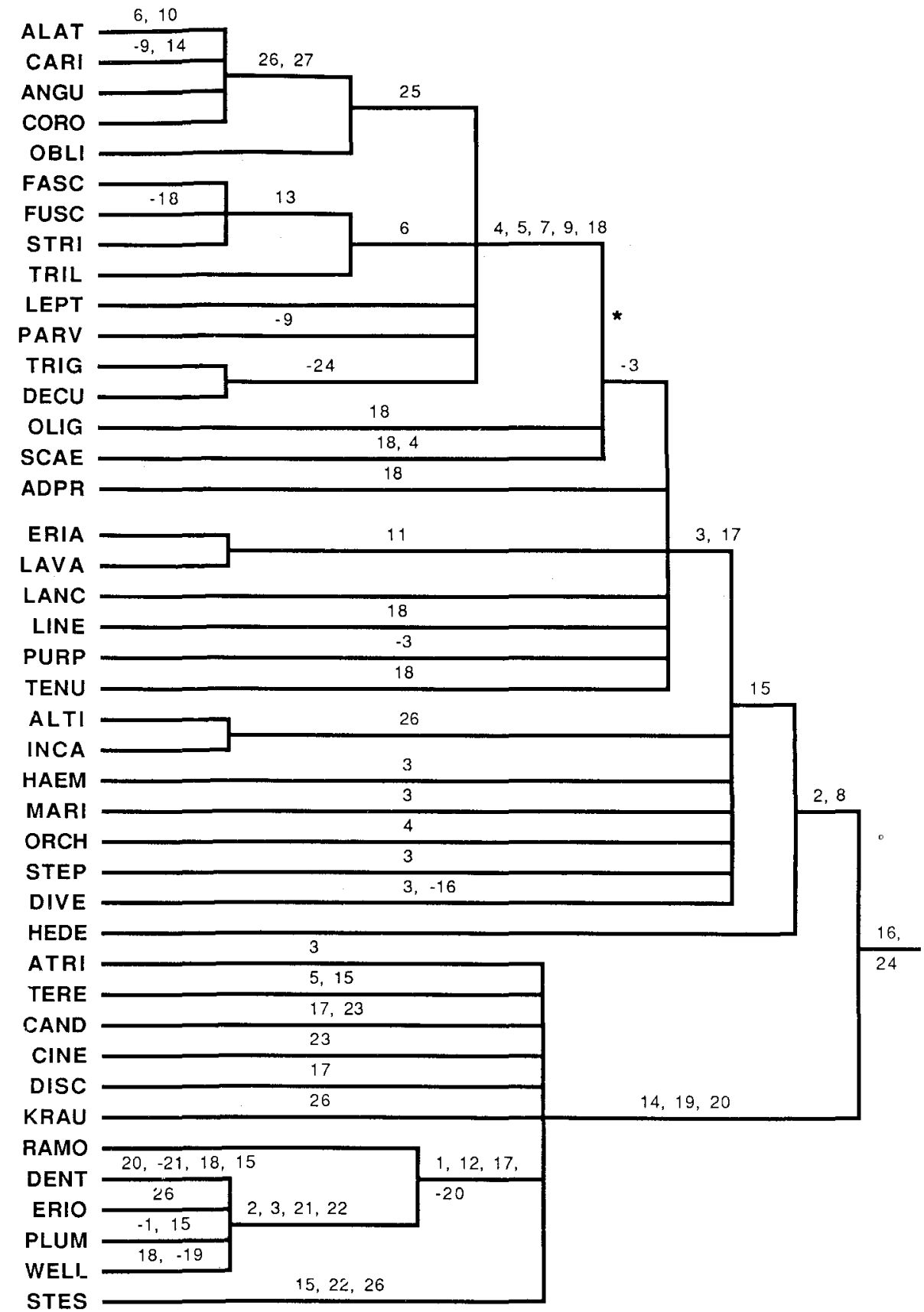

Fig. 4. Strict consensus cladogram from 100 trees generated by PAUP. Codes are the same as in Fig. 3. ${ }^{*}=$ point at which cladogram is redrawn to produce Fig. 5. 
Character 24 is the change to a unilocular ovary. In sect. Linschotenia the insertion of the ovule is often 'lateral' (Carolin 1959). This, again, may be due to a separate origin of the unilocular condition from those in sect. Dampiera. If these separate origins of characters 24 and 17 do, in fact, represent 'mistakes' in the recognition of homologies, then there is only one extra step involved in redrawing the cladogram as suggested. That is character 15 , the change to a sessile leaf, a feature which might well be rather homoplasic. Fig. 5 is our preferred cladogram since we think that more weight should be given to the non-reversal of the ovary condition than to a separate origin of the petiolate condition. In that case some taxonomic adjustment is necessary.

Sects. Cephalantha and Linschotenia were separated by Bentham (1868) on the basis of the former having a head of flowers. They should be grouped together. $D$. plumosa, for instance, has an inflorescence sometimes condensed into a head and sometimes spread into a thyrse. The basal leaves (character 12) also are not particularly distinctive since $D$. ramosa also has basal leaves. Moreover, the heads of flowers within the clade representing sect. Cephalantha are not exactly homologous since in $D$. eriocephala the head is formed from a thyrse like that of $D$. plumosa, whilst in $D$. dentata it is clearly a condensed spike; it is possible that this clade is more heterogeneous than the present analysis shows. Both cladograms also indicate that sect. Dicoelia and sect. Camptospora, as recognized by Bentham (1868) and Krause (1912), make sect. (Eu)Dampiera paraphyletic. Indeed $D$. obliqua represents an almost intermediate species between sects. Camptospora and (Eu)Dampiera of those authors. The proposed classification is shown on Fig. 5 and formally set out below.

Two sections are recognized. There is a fairly clear subdivision of sect. Dampiera into two subsections. Two names are available at section level for the subsection not containing the type species. They are sect. Dicoelia and sect. Camptospora. Both are inappropriate for the clade as a whole and a new name is proposed at subsectional level. Bentham's sect. Camptospora is a relatively clear 'grade' although $D$. obliqua does represent a transitional condition of the ovary. We are therefore proposing this as a series separate from the paraphyletic series Angulares. There is no doubt that grades are useful in some situations and it is counterproductive to discard the concept altogether. It does not seem necessary, however, to recognize sect. Cephalantha at any level at present.

\section{Systematic arrangement}

Dampiera $R$. Br., Prodr.: 587 (1810)

TYPE: $D$. incana $\mathrm{R}$. Br., here nominated.

\section{Sect. Dampiera}

Multicaulate plants often woody towards the base. Stems ribbed, grooved, triangular or flat. Phyllotaxis $2 / 5$ or more. Flowers in panicles, often appearing to be clustered, or solitary in the leaf axils.

\section{(i) Subsect. Dampiera}

Stems ribbed and/or grooved, sometimes triangular above. Phyllotaxis $2 / 5$. 


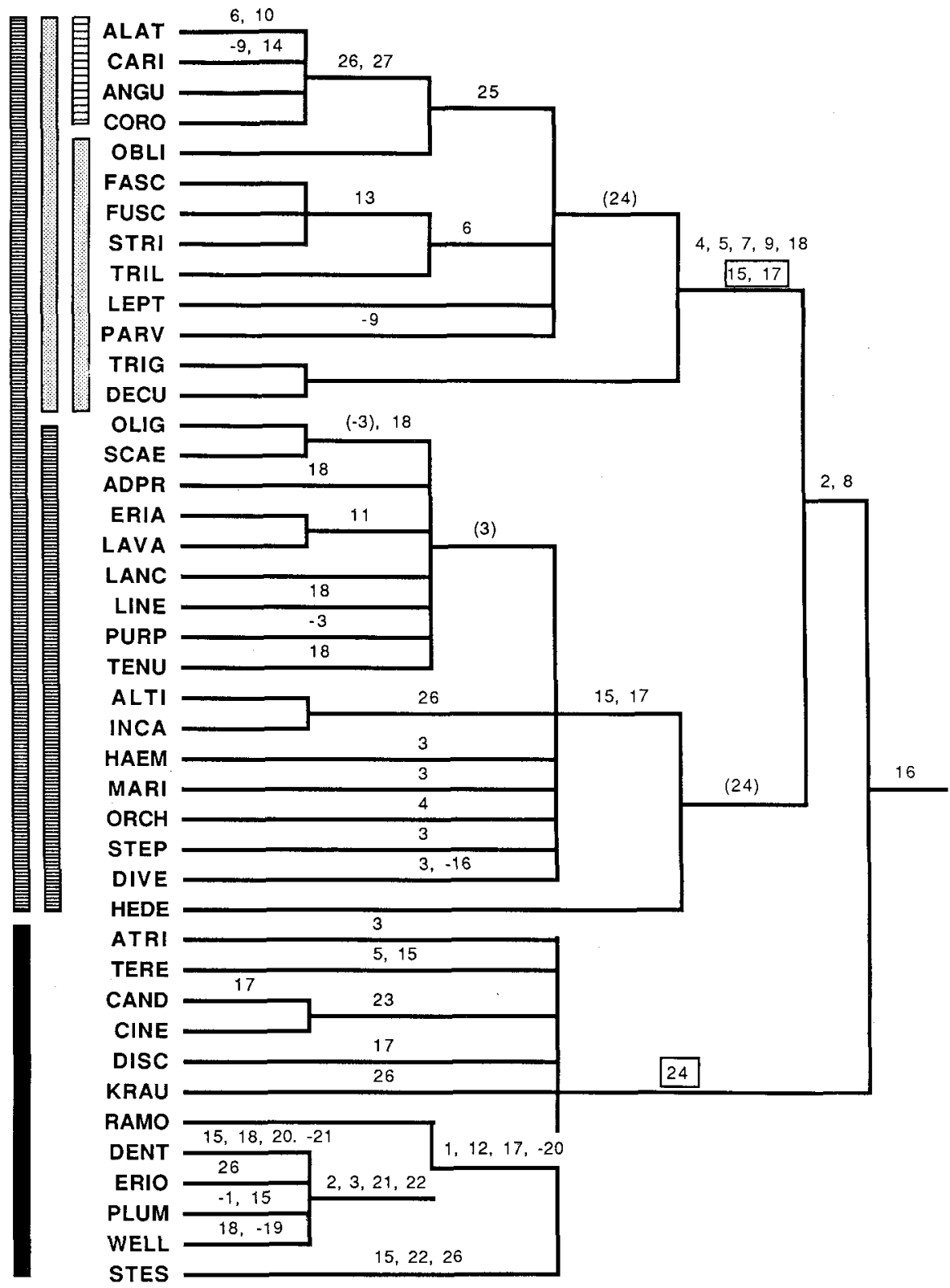

Fig. 5. Cladogram of Fig. 4 redrawn to eliminate the reversal of the ovary condition to bilocular. Differences in character state changes from Fig. 4 shown. Numbers in parentheses represent character state changes that cancel out; those which are enclosed in rectangles represent increases in length of the tree. Symbols at left represent sections, subsections and series respectively from left to right, as recognized here:
Camptospora
Angulares
Dampiera
Linschotenia

a 
(ii) Subsect. Angulares Rajput \& Carolin, subsect. nov.

TYPE: D. stricta R. Br.

Plantae multicaulatae. Caules triangulares vel compressi. Phyllotaxis $1 / 3$ vel $1 / 2$. Flores in paniculis vel fasciculis in axilis superioribus.

Stems triangular or flat. Phyllotaxis $1 / 3$ or $1 / 2$.

The name refers to the angled stems of the members of this Subsection.

Series Angulares

Sect. Dicoelia Benth. in Hook., Icon. Pl.: t.1026 (1866). TYPE: D. trigona De Vriese, here nominated.

Stems triangular. Ovary straight or oblique but not gibbous. Ovule straight.

Series Camptospora (Benth.) Rajput \& Carolin, stat. nov.

BAsIonym: sect. Camptospora Benth. in Hook., Icon. Pl.: t.1027 (1866). TYPE: D. alata De Vriese, here nominated.

Stems triangular, flat or compressed. Ovary gibbous. Ovule horseshoe-shaped.

Sect. Linschotenia Benth., Fl. Austral. 4: 107 (1868)

TYPE: $D$. discolor De Vriese, here nominated.

Sect. Cephalantha Benth., Fl. Austral. 4: 120 (1868). TYPE: D. eriocephala De Vriese, here nominated.

Subshrubs to rosette herbs. Stems terete. Phyllotaxis $1 / 5$ or less. Flowers in racemes or thyrses, sometimes condensed into heads.

\section{Typifications, new taxa and nomenclatural notes}

The species are arranged in the preferred taxonomic sequence derived from the results of the last section.

In this section holotypes are not considered unless we think a problem may exist. They will be indicated in the forthcoming volume of the 'Flora of Australia' and those species in which no such problems arise are not dealt with here.

When only one collection relates to the protologue this is shown by '*' after the type statement.

Lectotypes are here nominated. They may have had to be selected from more than one collection relating to the protologue. This is shown by '\#' following the type statement. There may be more than one sheet of the lectotype collection and where this choice is necessary it is indicated by the citation of isolectotypes. In all cases the specimen agreeing most closely with the protologue description is selected and where all agree well the most complete specimen is selected.

Preiss's collections, described in 'Plantae Preissianae', were distributed to the contributors as whole collections. Therefore the complete set of replicates was available to them in casting their descriptions. Subsequently a reference collection was lodged at LD (Crisp 1983). Whenever a specimen at LD is satisfactory it is selected as the lectotype. 
Robert Brown's collections also were distributed after they had served as the basis for his descriptions in the Prodromus, the reference set being lodged at BM. Other things being equal, we have selected the BM specimen as lectotype.

E. Pritzel's collections, described in Pritzel (1905), were also distributed after he used them for his descriptions. Unfortunately the reference set at B was destroyed during the 1939-1945 war. Duplicates of these specimens in other herbaria are selected as lectotypes with the usual restrictions stipulated by the Code.

Chromosome counts given here are from Peacock (1963).

The geographical range for each of the newly described species is given using the regions currently in use in the various State Herbaria, see Beard (1980) for W.A., Chippendale (1972) for N.T., Jessop \& Toelken (1986) for S.A., Beauglehole (1980) for Vict., Anderson (1961) for N.S.W. and MacLean (1886) for Qld.

In some cases only selected specimens are cited, with (in parentheses) the number cited followed by a '\% and the total number examined.

\section{Sect. Dampiera}

\section{(i) Subsect. Dampiera}

D. oligophylla Benth., Fl. Austral. 4: 115 (1868).

LECTOTYPE: Drummond 4th coll. no. 193 (K). IsOleCTOTYPES: BM, MEL. Bentham also cites 'Gordon and Kalgan River' with the protologue. We have found specimens labelled with this locality information in MEL, but none in $\mathrm{K}$, and have identified them as $D$. lavandulacea.

D. juncea Benth., Fl. Austral. 4: 115 (1868).

LECTOTYPE: Dummond no. 168 (K). ISOLECTOTYPE MEL\#

D stenophylla Krause, Pflrch. 54: 187 (1912).

LECTOTYPE: Victoria Desert, Camp 58, Helms, 1891 (K). Isolectotypes: AD 96620155, AD 97715448, MEL 516705*.

D. linearis R. Br., Prodr.: 588 (1810).

LeCtotyPE: King Georges Sound, R. Brown, Dec. 1801 (BM)*.

D. azurea De Vriese in Lehm., Pl. Preiss. 1: 400 (1845).

LECTOTYPE: in arenosis ad flumen Cygnorum, Preiss 1475, 25 juni, 1839 (LD 0489).

ISOLECTOTYPES: L $903311 \ldots 215$, L $903311 \ldots 216$, MEL 516715, W*.

D. eriophora De Vriese, op. cit.: 401.

Lectotype: In solo turfoso arenosa ad Stirlings Terrace, Plantagenet, Preiss 1500, sept. 1842 (LD 0492). ISOLECTOTYPES: L 90962 . . 297, MEL 516696, W.*

D. lanuginosa De Vriese, Nat. Verh. Holl. Maats. Wet. Haarlem 2: 81 (1854).

LECTOTYPE: Swan River, Drummond $127(\mathrm{~K})^{\# \text {. }}$

D. incana R. Br., Prodr.: 588 (1810).

Lectotype: Nov. Hollandia (occident.), W. Dampier, Herb. Sherrard 24, 1699 
$(\mathrm{BM})^{\#}$. There is only one specimen at BM but it is probable that Brown used the rest of Dampier's collection, now at Oxford and of which this is a fragment, to cast his diagnosis. Apparently Brown also had access to a specimen collected at Shark Bay by Baudin's expedition. This is also in BM.

D. incana var. fuscescens Benth., Fl. Austral. 4: 111 (1868).

Holotype: Murchison River, Oldfield $(\mathrm{K})^{*}$. There are three sprigs mounted on the same sheet at $\mathrm{K}$. The uppermost two seem to be D. spicigera, the lowest one is this holotype.

\section{D. scaevolina Gardner ex Rajput \& Carolin, sp. nov.}

Adscendens ad $60 \mathrm{~cm}$ caulibus teretibus costatis glabris vel sulcis tomentosis albidis. Folia sessilia lineari-oblonga $5-10 \mathrm{~mm}$ longa $1-5 \mathrm{~mm}$ lata \pm concava glabra fasciculata integra. Bracteolae 4-6 mm longae herbaceae. Corolla extus pilis appressis argenteis.

Holotype: Western Australia: Canna Siding, C.A. Gardner, Sept. 1934 (PERTH). ISOTYPE: PERTH.

Multicaulate perennial to $70 \mathrm{~cm}$. Stems terete, ribbed, glabrous except for the tomentose grooves. Leaves sessile, fasciculate, linear-oblong, 5-10 mm long, $1-1.5 \mathrm{~mm}$ wide, \pm concave, glabrous, entire. Peduncles $2-4 \mathrm{~mm}$ long, 2-3 together bearing a single flower, pubescent with silvery hairs; bracteoles 2 , leaflike, 4-6 mm long, c. $1 \mathrm{~mm}$ wide, glabrous on both surfaces. Sepals linear, $0.2-0.5 \mathrm{~mm}$ long, covered with silvery hairs. Corolla lobes blue or white, linearoblong, with silvery-white appressed type III hairs outside; inferior lobes 4.5-5.5 mm long, 0.5-0.7 mm wide; connate part of inferior lobes $2-3 \mathrm{~mm}$ long; superior lobes $6-7 \mathrm{~mm}$ long, $0.5-0.7 \mathrm{~mm}$ wide; auricle purplish, $0.5-1 \mathrm{~mm}$ wide; wing slightly veined, $1-1.5 \mathrm{~mm}$ wide, shorter above the auricle, obtuse at the top. Ovary 1-locular, c. $1.5 \mathrm{~mm}$ long, covered with appressed white hairs; ovule single, linear, c. $1 \mathrm{~mm}$ long, erect, basifixed; style $2.5-3 \mathrm{~mm}$ long, glabrous; indusium c. $0.5 \mathrm{~mm}$ diam., glabrous. Fruit similar to ovary.

RANGE: Irwin, Avon and Roe regions of Western Australia.

HABITAT: Sandy and gravelly soils.

DISCUSSION: This species resembles $D$. diversifolia but the former is distinguished by having erect stems, linear-oblong leaves and appressed silvery hairs on the outside of the corolla. See also $D$. fitzgeraldensis. The specific epithet refers to the resemblance of the flowers to those of some species of Scaevola, mainly due to the obtuse wings.

Selected Specimens EXAmined (5/10): Western Australia: Waddouring, W. $B$. Alexander 1241, x-1915 (PERTH); Beacon, C.F. Jenkins, 16-x-1960 (PERTH); 3 miles $(4.2 \mathrm{~km}) \mathrm{E}$ of Bencubbin, W.E. Blackall 3422, xi-1937 (PERTH); Approaching Wyalkatchem, M.E. Phillips, 19-ix-1962 (NSW 100413); NE of Newdegate and SE of Hyden, W.E. Blackall 1380, 19-ix-1931 (PERTH).

D. fitzgeraldensis Rajput \& Carolin, sp. nov.

Planta erecta ad $60 \mathrm{~cm}$. Caules canaliculati infra teretes sed versus apicem triangulares tomento albido in sulcis. Folia spathulata vel oblongo-elliptica 4-16 mm longa \pm revoluta tomentosa in pagina inferna. Bracteae atque bracteolae tomentosae in pagina externa. Sepala inaequalia. Corolla callis $6-13$ atque pilis albidis appressis externis.

Holotype: Western Australia: Ongerup-Ravensthorpe, Fitzgerald River, R.C. Carolin 3564, 11-9-1961 (NSW). 
Erect subshrub to $70 \mathrm{~cm}$. Stems terete, sometimes triangular above, ribbed, whitish pubescent in grooves. Leaves sessile, fasciculate, spathulate or oblongelliptic, 4-16 mm long, 1.5-6 mm wide, greyish-white or brownish-white tomentose below, glabrous above at maturity, dentate, slightly recurved. Flowers in cymes of 2-3 together; pedicels $1-3 \mathrm{~mm}$ long, hairy in patches; bract linear-oblong, 4-5.5 mm long, hairy outside; bracteoles 2, linear-oblong, 1-3 mm long, c. $0.5 \mathrm{~mm}$ wide, hairy outside. Sepals unequal, $0.5-1 \mathrm{~mm}$ long, c. $0.2 \mathrm{~mm}$ wide, hairy with silvery white hairs. Corolla lobes with \pm appressed silvery-white type II hairs outside; inferior lobes oblong-lanceolate, 3-4 mm long, 1-1.5 mm wide; connate part of inferior lobes 3-4 mm long; superior lobes falcate, 5-6 mm long, 1-1.2 mm wide; auricle purplish, c. $1.5 \mathrm{~mm}$ wide; wing slightly veined, c. $2 \mathrm{~mm}$ wide, slightly shorter above the auricle; calli 6-13 in each row. Ovary 1-locular, c. $1.5 \mathrm{~mm}$ long, covered with short whitish-grey appressed hairs; ovule single, oblong, c. $0.7 \mathrm{~mm}$ long, erect, basifixed; style 2-2.5 mm long, glabrous; indusium $0.8 \mathrm{~mm}$ diam., glabrous. Fruit similar to ovary.

RANGE: Eastern part of Darling-Menzies region of Western Australia. Known only from the type collection.

HABITAT: Sand plain heath.

DISCUSSION: This species is related to D. scaevolina but can be distinguished by its spathulate to oblong-elliptic leaves, which are tomentose below and have slightly revolute margins.

This species is named for the Fitzgerald River where the type specimen was collected.

\section{D. orchardii Rajput \& Carolin, sp. nov.}

Caules costati glabri teretiusculi internodiis longis atque tomentosis albidis ad nodos. Folia sessilia oblongo-elliptica lata ad basin $0.5-1.5 \mathrm{~mm}$ longa, $0.5-0.7 \mathrm{~mm}$ lata. Flores solitarii pedunculo $1-1.5 \mathrm{~mm}$ longo. Bracteae herbaceae. Corolla ovariumque pilis dendriticis adpressis stramineis obtecta. Calli corollae 5-9 parvi. Ovarium 3.5-4.5 mm longum.

Holotype: Western Australia: South-West Division, Shire of Oldfield, c. $58 \mathrm{~km}$ north of mouth of Oldfield River, A.E. Orchard 1709, 21-x-1968 (PERTH).

ISOTYPE: AD 97108544.

Stems erect, ribbed, branched, glabrous, golden-yellowish tomentose when young, whitish tomentose on the nodes, glabrescent or slightly whitish tomentose in the grooves. Leaves sessile, oblong-elliptic, 0.5-1.5 mm long, $0.5-0.7 \mathrm{~mm}$ wide, with wide base, pale yellowish tomentose or glabrescent, entire. Flowers solitary or in cymes; peduncles tomentose with golden-yellow short dendritic hairs, $1-1.5 \mathrm{~mm}$ long; pedicel $0.5-1 \mathrm{~mm}$ long, tomentose with short golden-yellow hairs; bract leaf-like, slightly tomentose outside or glabrescent, 1-2 mm long, $0.5-0.6 \mathrm{~mm}$ wide; bracteoles usually 2, oblong to narrow-elliptic, irregularly tomentose outside with golden-yellow dendritic hairs, $1-1.2 \mathrm{~mm}$ long, c. $0.5 \mathrm{~mm}$ wide. Sepals tomentose with golden-yellow hairs, $0.2-0.5 \mathrm{~mm}$ long, c. $0.3 \mathrm{~mm}$ wide. Corolla lobes with short appressed yellowish type III hairs outside; inferior lobes oblong-lanceolate, 3-4 mm long, c. $1 \mathrm{~mm}$ wide; connate part of inferior lobes $44.5 \mathrm{~mm}$ long; superior lobes falcate, 4-5 mm long, $1-1.5 \mathrm{~mm}$ wide; auricle brown c. $1.5 \mathrm{~mm}$ wide; wing $1.5-2 \mathrm{~mm}$ wide, slightly shorter above auricle; calli $5-9$ in each row. Ovary 1-locular, $3.5-4 \mathrm{~mm}$ long, hairy as corolla; ovule single, linear, $2-3 \mathrm{~mm}$ long, erect, 
basifixed; style 3-4 mm long, glabrous; indusium c. $1 \mathrm{~mm}$ diam., glabrous. Fruit obloid, 4-5 $\mathrm{mm}$ long, hairy.

RANGE: Eyre and Roe regions of Western Australia.

DISCUSSION: This species can be recognized by the tuft of whitish tomentum at the nodes and the almost golden-yellow hairs on the flowers. It is possibly close to $D$. tenuicaulis.

It is named for the collector of the holotype, A. Orchard, who is at present the Curator of the Tasmanian Herbarium.

SPecimens Examined: Western Australia: towards Tone River, Muir, 1880 (MEL 25733); Lake King to Ravensthorpe, B. Benn, 7-xi-1963 (SYD).

\section{D. salahae Rajput \& Carolin, sp. nov.}

Frutex adscendens. Caules teretes canaliculati tomento incano. Folia ovata ad obovata supra glabrescentia infra tomento incano margine papillata crassa integra. Sepala obsoleta. Corolla extus pilis longis typis II cinereis divergentibus instructa.

Holotype: Western Australia: Between Yula-Mullewa road [sic], A.M. Ashby 1591, 14-vii-1965 (MEL 516689).

Ascending closely pale grey to whitish (or yellowish when young) tomentose multicaulate perennial to $60 \mathrm{~cm}$. Stems terete, ribbed. Leaves sessile, ovate to obovate or elliptic-spathulate, 7-39 mm long, 5-21 mm wide, tomentose on both surfaces when young but glabrescent above, entire, with a thick papillate margin. Peduncles 15-55 mm long, 1-3 together, each with 1-3 flowers; pedicels 1-3 mm long, tomentose; bract 4-8 $\mathrm{mm}$ long, leaf-like, tomentose; bracteole oblong, 3-5 mm long, tomentose. Sepals obsolete. Corolla lobes with a dense indumentum of spreading silky greyish type II hairs outside; inferior lobes oblong-lanceolate, $5-7 \mathrm{~mm}$ long, 1-1.5 mm wide; connate part of inferior lobes $3.5-4.5 \mathrm{~mm}$ long; superior lobes falcate, $4.5-5.5 \mathrm{~mm}$ long, $1.5-2 \mathrm{~mm}$ wide; auricle purplish, $1.5-2 \mathrm{~mm}$ wide; wing slightly veined, $1.5-3 \mathrm{~mm}$ wide, usually shorter above the auricle; calli 5-9 in each row. Ovary oblique, 1-locular, to $2.5 \mathrm{~mm}$ long, hairy as corolla; ovule single, bent, $1-1.5 \mathrm{~mm}$ long, basifixed; style 3-3.5 mm long, glabrous; indusium c. $1 \mathrm{~mm}$ diam., 2-lipped, glabrous. Fruit globular-oblique, c. $3 \mathrm{~mm}$ long, hairy.

RANGE: Irwin region of Western Australia.

HABITAT: Sand plains and lateritic soils.

Chromosome Number: $n=18$, Peacock 60841.1 (SYD), as D. altissima.

DISCUSSION: This species is similar to $D$. altissima but can be distinguished from that species by its ovate to obovate leaves, which are entire and thickened at the margin and glabrous above at maturity. In addition the sepals are obsolete and the hairs on the outside of the corolla are silky.

The species is named for the beloved wife of the senior author who has helped so much with his researches.

Selected Specimens Examined (11/22): Western Australia: East Yuna, NE of Geraldton, A.C. Burns 15, 5-vi-1966 (PERTH); Pindar, Sharr 2716, 1968 (PERTH); Pindar just $\mathrm{E}$ of Mullewa, W.E. Blackall 680, 20-ix-1931 (PERTH); 3 miles $(4.8 \mathrm{~km})$ from Mullewa towards Pindar, M.E. Phillips, 20-ix-1968 (SYD); Wilroy c. $96 \mathrm{~km} \mathrm{E}$ of Geraldton, A.M. Ashby 328, 6-ix-1963 (AD 9640054); Tardun, J.B. Cleland, 26-viii-1948 
(AD 97234190); Canna, J.L. McMullan, 28-vii-1959 (PERTH); 17 miles (27.2 km) E of Mingenew, K. Newby 2124, 26-vii-1965 (PERTH); Morawa, B.Benn, 10-x-1963 (SYD); Irwin River, F.W. Went 240, 5-ix-1962 (PERTH); 6 miles $(9.6 \mathrm{~km})$ from Three Springs towards Arrino, M.E. Phillips, 14-ix-1968 (PERTH).

\section{D. tephrea Rajput \& Carolin, sp. nov.}

Frutices tomentoso cinerei obtecti et caulibus striatis teretibus. Folia obovata elliptica plerumque dentata glabrescentes in pagina dorsali. Flores 2-3 in ramis brevibus foliosis dispositi. Bracteae ovato-ellipticae tomento albicanti obtectae. Corolla pilis dentriticis et plumosis extus. Ovarium oblongum vel obscure gibbosum c. $2.5 \mathrm{~mm}$ longum ovulo solitario hippocrepico in loculo.

Holotype: Western Australia: 7 miles $(11.2 \mathrm{~km})$ from Dongara towards Eneabba, M.E. Phillips s. d. (CANB). IsOTYPE: SYD.

Ascending to erect multicaulate perennial to $60 \mathrm{~cm}$. Stems terete, ribbed, pale-grey tomentose. Leaves sessile, spathulate, $15-47 \mathrm{~mm}$ long, 5-15 mm wide, fasciculate, closely ashy-grey tomentose below, glabrous or glabrescent above, dentate or sometimes entire. Peduncles $9-20 \mathrm{~mm}$ long, 1-3 together, usually with a single flower, tomentose; bracts ovate-elliptic, $2-3.5 \mathrm{~mm}$ long, tomentose on both surfaces; bracteoles linear-oblong, 1.5-6 $\mathrm{mm}$ long, tomentose on both surfaces. Sepals obscured by hairs, $0.7-1.4 \mathrm{~mm}$ long, c. $0.5 \mathrm{~mm}$ wide. Corolla lobes narrow-oblong, with loose ash-grey type I and II hairs outside; inferior lobes 5.5-6 mm long, 1.2-1.5 mm wide; connate part of inferior lobes 4-4.7 mm long; superior lobes $7.5-8 \mathrm{~mm}$ long, $1.3-1.6 \mathrm{~mm}$ wide; auricle purple to red, $\mathrm{c}$. $1.5 \mathrm{~mm}$ wide; wing veined, $1.7-2 \mathrm{~mm}$ wide, smaller above the auricle; calli $2-7$ in each row. Ovary 1-locular, oblong or very slightly gibbous, c. $2.5 \mathrm{~mm}$ long, loosely tomentose; ovule single, curved, c. $2 \mathrm{~mm}$ long, basifixed; style $3-4 \mathrm{~mm}$ long, glabrous; indusium $1.2-1.5 \mathrm{~mm}$ diam, glabrous. Fruit globular-oblique, c. $2 \mathrm{~mm}$ diam., hairy, \pm rugose.

RANGE: Irwin region of Western Australia around Dongara and Eneabba.

\section{HABITAT: Heath.}

DISCUSSION: This species can be distinguished from D. incana var. fuscescens by its spathulate leaves which are glabrescent above at maturity. It is also similar to $D$. salahae but the close pale grey to whitish tomentum of the latter distinguishes it. The specific epithet refers to the grey colour of the hairs on the leaf.

Specimens Examined: Western Australia: Dongara, R.C. Carolin 10673, 12-viii-1978 (SYD); c. $10 \mathrm{~km} \mathrm{~N}$ of Eneabba, R.C. Carolin 10628, 12-viii-1978 (SYD).

D. tenuicaulis E. Pritzel, Bot. Jahrb. Syst. 35: 580 (1905).

TYPE: Coolgardie, C.L. Webster, 1898 (B-destroyed). No other specimens from this collection have been traced to date. The following specimen has been selected to replace the type because, of the collections made to date, it agrees most closely with Pritzel's description and was collected in the same area. NEOTYPE: Coolgardie, C.A. Gardner, Sept. 1934 (PERTH). IsONEOTYPE: K.

D. purpurea R. Br., Prodr.: 588 (1810).

LECTOTYPE: Banks of the Grose River, forest land, R. Brown, 1803 (BM). ISOLECTOTYPES: K, MEL 516699*. 
D. ovalifolia R. Br., op. cit.: 588 .

LECTOTYPE: Lane Cove, R. Brown, 1803 (BM). IsOLECTOTYPE: $\mathrm{K}^{*}$.

D. rotundifolia $\mathrm{R}$. Br., op. cit.: 587 .

LECTOTYPE: Grose and Portland Head, $R$. Brown (BM). Isolectotype: K*.

D. undulata R. Br., op. cit.: 587.

LECTOTYPE: Georges River, $R$. Brown, Oct. 1803 (BM). IsOLECTOTYPE: K*.

D. nervosa De Vriese, Nederl. Kruidk. Arch. 2: 12.

LECTOTYPE: Glenbrook, $R$. Cunningham (W)\#.

D. omissa De Vriese, op. cit.: 10.

LECTOTYPE: Argylle-Paramatta, Huegel (W) ${ }^{\#}$.

D. melanopogon De Vriese, op. cit.: 12 (1851), nom. illegit.

Since De Vriese cites $D$. omissa De Vriese in the protologue of this name, it is superfluous.

D. brownii F. Muell., Fragm. 6: 29 (1866), nom. illeg.

Since Mueller cites $D$. undulata, $D$. rotundifolia, $D$. ovalifolia, and $D$. purpurea in the protologue of this name, it is superfluous and thus illegitimate. Mueller's description clearly refers to the species now known as $D$. purpurea.

D. ferruginea R. Br., Prodr.: 588 (1910).

LECTOTYPE: Shoalwater passage, $R$. Brown, 26-8-1802 (BM). ISOLECTOTYPE: MEL*.

D. pedunculata Rajput \& Carolin, sp. nov.

Caules teretes basaliter sed triangulares versus apicem. Folia sessilia glabra linearia vel lineari-oblonga fasciculata dentata. Flores in pendunculis $16-48 \mathrm{~mm}$ longis dispositi. Sepala obsoleta. Corolla extra pilis brevis dentriticis nigris atque longis plumosis griseis. Ovarium 3-4 mm longum.

Holotype: Western Australia: Ruabon, R.D. Royce 4516, 29-9-1953 (PERTH).

Ascending to decumbent multicaulate perennial to $70 \mathrm{~cm}$. Stems triangular above terete below, glabrous. Leaves sessile, very rarely in whorls, linear to linear-oblong, $10-35 \mathrm{~mm}$ long, $1.5-4 \mathrm{~mm}$ wide, glabrous, dentate. Peduncles 16-18 mm long, 1-4 together in the axils of the upper leaves, glabrous or slightly tomentose each with 3-4 flowers; bract linear, 4-9 $\mathrm{mm}$ long, 1-2 $\mathrm{mm}$ wide, glabrous; bracteole linear-oblong, 5-7 mm long, 1.5-2 mm wide, glabrescent or 
hairy outside, glabrous inside. Sepals obsolete. Corolla lobes linear-lanceolate, with short dark grey to black type I and long grey type II hairs outside; inferior lobes $6.5-7.5 \mathrm{~mm}$ long, c. $1 \mathrm{~mm}$ wide; connate part of inferior lobes $4-5 \mathrm{~mm}$ long; superior lobes $7-8.5 \mathrm{~mm}$ long, c. $1.5 \mathrm{~mm}$ wide; auricle light brown to yellow, c. $1.5 \mathrm{~mm}$ wide; wing veined, c. $2.5 \mathrm{~mm}$ wide, tapering towards the apex above the auricle; calli $7-12$ in each row. Ovary unilocular, hairy as corolla, 3.5-4 mm long; ovule single, linear, $2.5-3 \mathrm{~mm}$ long; ovule single, linear, 2.5-3 mm long, basifixed, erect; style glabrous, $3.5-4 \mathrm{~mm}$ long; indusium glabrous, 2-lipped, brown, c. $1 \mathrm{~mm}$ diam. Fruit similar to ovary.

RANGE: Drummond, Darling-Menzies and Warren regions of Western Australia.

HABITAT: In swampy and sandy soils.

Discussion: This species is close to $D$. linearis, but it can be distinguished from that species by the linear-oblong leaves, which are distinctly dentate, and the long peduncles to which the specific epithet refers.

Selected Specimens Examined (3/12): Western Australia: Welshpool to Kalamunda, J.H. Maiden, ix-1909 (NSW); NE of Albany at Oyster Harbour, A.M. Ashby, 1978 (AD 96732185); Bayonet Head Track c. $8 \mathrm{~km}$ NE of Albany, A.M. Ashby 1998, 11-x-1966 (AD, SYD).

D. lavandulacea Lindl., Swan River App.: 27 (1839).

LeCTOTYPE: Swan River, Drummond, 1839 (CGE)\#. Three specimens are mounted on this sheet. One is $D$. linearis, the other two are $D$. lavandulacea. It is probable that both these specimens of $D$. lavandulacea were used by Lindley to cast his diagnosis. The Drummond specimen is selected since it agrees most closely with his description.

D. preissii De Vriese in Lehm., Pl. Preiss. 1: 403 (1845).

LECTOTYPE: In solo limoso-calculoso sylvae districtus York, Preiss 1481, 12 Sept. 1839 (LD 0493). IsOLECTOTYPE: MEL 516672*. The sheet L 903311 ..220 bears two Preiss numbers, 1501 and 1481, but only one specimen. This specimen is Goodenia incana. In fact De Vriese, loc. cit., identified Preiss 1501 as Scaevola pterygosperma, a synonym of $G$. incana. It seems the specimen of Preiss 1481 in L is mislaid.

D. rosmarinifolia var. dysantha Benth., Fl. Austral. 4: 144 (1868).

LECTOTYPE: Grampians, Wilhelmi $(\mathrm{K})^{\#}$.

\section{D. rodwayana Rajput \& Carolin, sp. nov.}

Caules teretiusculi vel angulati versus apicem tomento cineraceo. Folia sessilia linearia recurvata interdum fasciculata ad oblongo-lanceolata glabra in pagina supra sed tomento cineraceo infra. Bracteae lineari-oblongae. Corolla pilis brevis dendriticis ad plumosis tenuibus argenteis.

Holotype: New South Wales: ca. 15 miles $(24 \mathrm{~km}) \mathrm{SW}$ of Nowra, Nowra-Nerriga road, Turpentine Range, E.F. Constable, 27-x-1957 (NSW 45259). ISOTYPE: MEL 75406. 
Erect multicaulate perennial to $60 \mathrm{~cm}$. Stems terete below, \pm triangular above, white-greyish tomentose. Leaves sessile, linear to linear-oblong or oblong-lanceolate or rarely oblong to narrow-elliptic, 9-30 mm long, 1-6 mm wide, with scattered hairs above when young but glabrous when mature, whitish tomentose below, entire or with a few teeth, recurved, tending to be fasciculate in the axils of the leaves on the main stem. Peduncles 1-5 mm long, covered with fine villous whitish hairs, each with 1-3 flowers; pedicels $1-2 \mathrm{~mm}$ long, covered with fine plumose or villous hairs; bract linear-oblong, 2-4 mm long, c. $1 \mathrm{~mm}$ wide, covered with pale grey hairs; bracteoles 1-2, linear-oblong, 3-6.5 mm long, 0.7-1 mm wide, 1-2 together, covered outside with plumose hairs. Sepals concealed under the hairs of the ovary, $0.5-1 \mathrm{~mm}$ long, $0.1-0.3 \mathrm{~mm}$ wide. Corolla lobes with fine silvery-grey type II hairs outside; inferior lobes oblong-lanceolate, 5.5-7 mm long, 1-1.2 mm wide; connate part of the inferior lobes 3.5-4 mm long; superior lobes falcate, $6-7 \mathrm{~mm}$ long, $1-1.3 \mathrm{~mm}$ wide; auricle purple-red, $1.2-1.4 \mathrm{~mm}$ wide; wing veined, $1.5-2.5 \mathrm{~mm}$ wide; calli obsolete. Ovary unilocular, covered with short dendritic and long plumose hairs, 2-2.5 mm long; ovule single, oblong, c. $1.5 \mathrm{~mm}$ long, basifixed; style $3.5-4 \mathrm{~mm}$ long, glabrous; indusium $0.7-1 \mathrm{~mm}$ long, c. $1 \mathrm{~mm}$ wide, glabrous. Fruit obovoid, $3-3.5 \mathrm{~mm}$ long, hairy as the ovary.

RANGE: South coastal region of New South Wales.

HABITAT: Sclerophyll woodland and heath on sandstone.

Chromosome Number: $n=18$, Peacock 6110.17.1 (SYD) as Dampiera sp.

Discussion: This species is related to $D$. rosmarinifolia but can be distinguished by the tomentose stems, the linear or linear-oblong leaves which are glabrous on the upper surface and tomentose on the lower surface and which have margins recurved but not so as to hide the lower surface, and the fine type II silvery hairs on the outside of the corolla.

This species is named in the honour of F.A. Rodway, who collected many plants in the Nowra region, amongst them the present species, but unfortunately none of his specimens is suitable as a type.

Selected Specimens Examined (6/12): New South Wales: $8 \mathrm{~km}$ W of Nowra on Yalwal road, D.F. Blaxell 447, 7-xii-1970 (NSW); 5 miles $(8 \mathrm{~km})$ W of Nowra, Herbarium F.A. Rodway 5484-5, (NSW); Flat Rock Dam, 2 miles $(3 \mathrm{~km}) \mathrm{SW}$ of Nowra, Herbarium F.A. Rodway 14612 (NSW); Turpentine Range, Nowra to Nerriga road c. 15 miles $(24 \mathrm{~km}) \mathrm{SW}$ of Nowra, E.F. Constable, 27-x-1957 (NSW 45259, MEL 75406); Jervis Bay, F.A. Rodway 5488, 15-ix-? (NSW); Box Point to Barbers Creek, J.H. Maiden, 101898 (NSW).

D. lanceolata A. Cunn. ex DC., Prodr. 7: 503 (1839).

LECTOTYPE: ad vallem Wellingtonianum et in siccis circa Bathurst, Cunningham (BM). IsOlectoTYPE: $\mathrm{K}^{*}$. Three sprigs are mounted on the sheet at $\mathrm{K}$ but only one, labelled Wellington Valley, appears to be an isolectotype.

D. maideniana Krause, Pflrch. 54: 189 (1912).

NEOTYPE: 50 miles north of Rylestone, R.T. Baker (NSW). It is not clear whether Krause saw this duplicate of the specimen in $B$ which has been destroyed ${ }^{\#}$. 
D. diversifolia De Vriese in Lehm., Pl. Preiss. 1: 403 (1845).

LECTOTYPE: In regionibus interioribus Aust. Occ., Preiss 1469 (LD 0494). ISOLECTOTYPES: L 90962 .. 293, pro parte, MEL 516677. Two elements occur on the sheet at Leiden. One appears to be a portion of Preiss 1504 which is a type of $D$. prostrata; the other part agrees well with De Vriese's description of D. diversifolia.

D. marifolia Benth., Fl. Austral. 4: 114 (1868).

LECTOTYPE: Wimmera, Dallachy (K). ISOLECTOTYPE: MEL\#.

D. haematotricha De Vriese, Nederl. Kruidk. Arch. 2: 12 (1851).

NEOTYPE: Drummond suppl. 56, no. 105, 1843 (MEL 516692). We have been able to locate only this one duplicate of the type collection and De Vriese probably did not see it.

\section{(ii) Subsect. Angulares}

Series Angulares

D. prostrata De Vriese in Lehm., Pl. Preiss. 1: 403 (1845).

LECTOTYPE: In solo arenoso prope Avondale, 10 Aprilis 1840, Preiss 1504 (LD 0494). IsolectotyPE: L $90962 \ldots 292$. This is a Scaevola species which cannot be identified at present, see below.

\section{D. decurrens Rajput \& Carolin, sp. nov.}

Caules triangulares glabri subalati prope basin folii cujusque. Folia glabra ovata vel ovato-elliptica basibus latis dentata $12-41 \mathrm{~mm}$ longa 5-23 mm lata. Pedunculus glaber. Bracteae atque bracteolae glabrae. Sepala obsoleta. Corolla pilis adpressis griseis extus obtecta. Ovarium biloculatum glabrum.

Holotype: Western Australia: Lucky Bay, Esperance, E.M. Bennett 882, 10 Sept. 1966 (PERTH).

[MisAPPlied NAME: D. prostrata auct. non De Vriese: Benth., Fl. Austral. 4: 110 (1868).]

Stiff erect multicaulate perennial to $1 \mathrm{~m}$. Stems triangular, slightly winged near the leaf base, glabrous. Leaves sessile, ovate or ovate-elliptic with a broad base, $12-41 \mathrm{~mm}$ long, 5-23 mm wide, with a few scattered hairs when young but glabrescent, dentate to lobed. Peduncles 11-17 mm long, glabrous, mostly in the upper axils; pedicels $3.5-5.2 \mathrm{~mm}$ long, glabrous or glabrescent; bract linear, $5.5-6.7 \mathrm{~mm}$ long, $1-1.2 \mathrm{~mm}$ wide, glabrous; bracteole linear-oblong, $3.2-4.7 \mathrm{~mm}$ long, $0.5-0.7 \mathrm{~mm}$ wide, glabrous. Sepals obsolete. Corolla lobes covered outside with fine appressed grey type IV hairs; inferior lobes 9-10.5 mm long, 1.2-1.5 mm wide; connate part of the inferior lobes $3-4.2 \mathrm{~mm}$ long; superior lobes $10-12.5 \mathrm{~mm}$ long, $1.7-2 \mathrm{~mm}$ wide; auricle purple, $1.7-2 \mathrm{~mm}$ wide; wing distinctly veined, 3.5-4 mm wide, short or sometimes obsolete above auricle; calli $2-5$ in each row. Ovary bilocular, glabrous, $3.5-4 \mathrm{~mm}$ long; ovules 1 in each loculus, oblong, erect, $2.7-3.2 \mathrm{~mm}$ long, basifixed; style $2.7-3.5 \mathrm{~mm}$ long, glabrous; indusium dark brown, $1.4-1.5 \mathrm{~mm}$ diam. 
RANGE: Eyre region of Western Australia.

HABITAT: On granite.

Discussion: This species has previously been referred to $D$. prostrata De Vriese. The types of $D$. prostrata De Vriese in Lehm. (see above), however, belong to a Scaevola species. Subsequently De Vriese (Nat. Verh. Holl. Maats. Wet. Haarlem, 2: 83; 1854) altered the circumscription of $D$. prostrata and cited one specimen alone, 'Drummond no. 364'. It is this latter concept, that apparently does not include the lectotype, which Bentham accepted. A name is supplied here for this second species. The specific epithet refers to the decurrent leaf margins. $D$. decurrens is quite different from the only other species with a 2-locular ovary, D. trigona which is a much smaller, more herbaceous plant.

Selected Specimens Examined: (6/9): Western Australia: Cheyne Beach fishery, Maxwell (MEL 42165); Recherche Archipelago, Sandy Hook Island, J.H. Willis, 10-xi1950 (MEL); Drummond 364 (MEL 42166); Mt. Gardner, Maxwell (MEL 42163); Lucky Bay, A.S. George 7461, 21-i-1966 (PERTH, SYD); Cape Le Grande, J.W. Wrigley, 30-x1968 (CBG 028785, SYD).

D. trigona De Vriese in Lehm., Pl. Preiss. 1: 401 (1845).

LECTOTYPE: In depressis humosis hiems aqua inundatis haud longe a praedio rustico Maddington, Preiss 1471, 2-11-1839 (LD 0499). ISOLECTOTYPES: L $903311 \ldots 225$, L $903311 \ldots 226$, L 903311..300, MEL 516710, MEL 516711, $\mathrm{W}^{*}$.

D. latealata (E. Pritzel) Rajput \& Carolin, stat. nov.

BAsIONYM: D. trigona var. latealata E. Pritzel, Bot. Jahrb. Syst. 35 : 578 (1905).

Holotype: Western Australia: in Dist. Coolgardie per Dundas in granitica inter frutices, Diels 5257 (B-destroyed).

Neotype: Western Australia: 27 miles (43 km) north on Eyre Highway, J.H. Willis, 3-x-1961 (MEL 1510118).

D. repanda De Vriese in Lehm., Pl. Preiss. 1: 400 (1845).

LECTOTYPE: In arenosis ad rivulam inter urbiculas Perth et Guildford, Preiss 1518, 29 Nov. 1839 (LD 0495). IsOLECTOTYPES: K, L 90962 ...338, W*.

D. parvifolia R. Br., Prodr.: 589 (1810).

LECTOTYPE: Bay 1 Ora Austral: N. Holl.; R. Brown, 13 January 1802 (BM). ISOLECTOTYPE: MEL 516698*.

D. galbraithiana Rajput \& Carolin, sp. nov.

Caules glabri triangulares foliis sessilibus oblongo-ellipticis glabris ad marginem grosse dentatis ac recurvatis incrassatis. Pedunculis uno ad tribus in axilis quoque idem flore solitario. Corolla extra tomentosa pilis adpressis cinereis typis IV. 
Holotype: Victoria: 2.5 miles $(4 \mathrm{~km}) \mathrm{E}$ of Cheynes Bridge on Macalister River on N-S track, J.H. Willis, 20-10-1973 (MEL 503635). IsOTYPES: AD, CANB, MEL 75410.

[MISAPPLIED NAME: D. scottiana auct. non F. Muell.: Galbraith, Victorian Naturalist 93:161 (1976).]

Erect multicaulate perennial to $1 \mathrm{~m}$. Stems \pm ribbed, triangular, glabrous. Leaves sessile, oblong-elliptic rarely rhomboid or lanceolate, $12-45 \mathrm{~mm}$ long, 3-17 mm wide, glabrous or slightly tomentose when young, deeply dentate with a prominent mid-rib, recurved or thickened at the margin. Peduncles 3-9 $\mathrm{mm}$ long, 1-3 in the axils of the upper leaves each usually with one flower, hairy with appressed grey hairs; bracts oblong-elliptic, $1.5-3 \mathrm{~mm}$ long, c. $0.5 \mathrm{~mm}$ wide, glabrous; bracteoles 1-2, linear-oblong, c. $1 \mathrm{~mm}$ wide, glabrescent. Sepals usually unequal, $0.5-1 \mathrm{~mm}$ long, irregularly covered with grey hairs. Corolla lobes with appressed very dark grey type IV hairs outside; inferior lobes linearoblong, 5.5-7 mm long, 0.7-1 mm wide; connate part of inferior lobes 3-4 mm long; superior lobes slightly falcate, $7-8 \mathrm{~mm}$ long, $1.5-2 \mathrm{~mm}$ wide; auricle purple to deep red $1.5-2 \mathrm{~mm}$ wide; wing veined, $1-1.5 \mathrm{~mm}$ wide, as wide as others above auricle; calli 5-6 in each row. Ovary 1-locular, hairy with dark grey hairs, 2-3 mm long; ovule single, linear-oblong, 1.5-2 mm long, erect, basifixed; style glabrous, 3.5-4 mm long; indusium glabrous, c. $1 \mathrm{~mm}$ diam. Fruit obloid, to $3 \mathrm{~mm}$ long, glabrescent or less hairy than the ovary.

RANGE: Eastern Region of Victoria.

DISCUSSION: This species can be distinguished from $D$. stricta by its deeply dentate leaves and the appressed grey hairs on the outside of the corolla. Moreover the leaves are very seldom found in pseudowhorls as in $D$. stricta.

The species is named for Jean Galbraith, the Victorian naturalist.

SPECIMENS EXAMINED: Victoria: Grid S 27 between Mt. Wellington and Mt. Kent, Jean Galbraith, 18-vi-1973 (MEL 57409); c. 9.5 miles (15.2 km) SSE of Licola, J.H. Willis \& A.C. Beauglehole \& E.A. Chesterfield ACB 43382, 21-x-1973 (SYD); a mile (1.6 km) or more $\mathrm{E}$ of McMillans Lookout, E.A. Chesterfield, 21-x-1973 (MEL 75408).

\section{D. fusca Rajput \& Carolin, sp. nov.}

Caules triangulares papillati tomentosi pilis fuscis vel glabrescentes. Folia oblongo-lanceolata vel rhombo-spathulata irregulariter utrinque tomentosa. Folia summa pseudo-fasciculata. Flores in cymis condensatis dispositi bracteolis duabus oblongis, corolla extus pilis semiadpressis fuscis.

Holotype: New South Wales: Kydra Peaks, K.C. Rogers \& J.H. Willis, 11th Jan. 1970 (MEL 501963).

Erect multicaulate perennial to $30 \mathrm{~cm}$. Stems triangular, slightly ribbed, tomentose with light-brown to grey dendritic hairs or glabrescent, papillate. Leaves sessile, oblong-lanceolate or spathulate-rhomboid, 8-22 mm long, $2-8 \mathrm{~mm}$ wide, irregularly tomentose on both surfaces or glabrescent, papillate, slightly recurved, dentate; upper leaves usually in pseudowhorls. Peduncles 4-15 mm long, clustered in the upper axils, each with 1-3 flowers, with brown dendritic hairs; pedicels $1-2.5 \mathrm{~mm}$ long, covered with brown-grey hairs; bract oblong-lanceolate, 5-7 mm long, 1.5-2 mm wide, covered with brown-grey dendritic hairs or glabrescent; bracteoles 2, oblong, 6-7.5 mm long, 1-1.2 mm wide, covered outside with brown-grey hairs, glabrous inside. Sepals obscured by hairs, $0.4-0.7 \mathrm{~mm}$ long, c. $0.3 \mathrm{~mm}$ wide. Corolla lobes oblong-lanceolate, with semi-appressed brown-grey type $V$ hairs outside; inferior lobes 4-6 mm 
long, 0.7-1 mm wide; connate part of the inferior lobes $3-3.5 \mathrm{~mm}$ long; superior lobes slightly falcate, $5-6.5 \mathrm{~mm}$ long, $0.7-1 \mathrm{~mm}$ wide; auricle purple, $1-1.2 \mathrm{~mm}$ wide; wing veined, 1-2 mm wide, slightly shorter above auricle; calli $0-2$ in each row. Ovary unilocular, covered with brownish appressed hairs, $1.5-2 \mathrm{~mm}$ long; ovule single, oblong, $1.2-1.5 \mathrm{~mm}$ long, erect, straight, basifixed; style glabrous, 3-3.5 mm long; indusium glabrous, dark-brown, 2-lipped, 0.4-0.5 mm long, c. $1 \mathrm{~mm}$ diam. Fruit obloid, usually less tomentose than the ovary or glabrescent, 2-3 mm long.

RANGE: South coast region and adjacent tablelands of New South Wales.

HABITAT: On sandstone.

DISCUSSION: This species is close to $D$. stricta, but it can be distinguished from that species by its stems and leaves which are tomentose at first, by the two bracteoles, which are tomentose, and by the brown-grey semi-appressed dendritic hairs on the outside of the corolla, which are referred to by the specific epithet.

SPecimens Examined: New South Wales: 1.5 miles $(2.4 \mathrm{~km})$ from Diggers Hole Track, A.C. Beauglehole ACB 41403, 6-ii-1972 (MEL 518208).

D. stricta var. laxa Benth., Fl. Austral. 4: 116 (1868).

LECTOTYPE: Mt. Macedon, F. Mueller (K)\# .

D. scottiana F. Muell., Fragm. 11: 120 (1881).

LECTOTYPE: Port Jackson, Woolls (MEL 16702). IsOLECTOTYPE: K*. There are two specimens in MEL. One has a letter from Harriet Scott pinned to it indicating that she first sent the specimen of this species to Mueller via Woolls and thanking him for naming the species after her. The letter is dated 15-8-1881. It seems that Mueller used only the specimen from Woolls to cast his description. Although the specimen at $\mathrm{K}$ has corolla hairs intermediate between those typical of $D$. stricta and those described in Mueller's diagnosis of $D$. scottiana, it is probable that this specimen was used by Mueller in casting his description and subsequently was sent to Bentham.

\section{D. sylvestris Rajput \& Carolin, sp. nov.}

Caules acute triangulares. Folia lineari-oblonga ad oblongo-elliptica plerumque integra. Sepala lineari-oblongi. Flores pilis divergentibus cinereis obtecti. Ovarium oblongum uniloculatum.

Holotype: New South Wales: Peach Mountain, Whian Whian State Forest, 15 miles $(24 \mathrm{~km})$ North of Lismore, K. Grieves, 3-10-1967 (NSW 138381).

Erect multicaulate perennial to $70 \mathrm{~cm}$, \pm woody at the base. Stems triangular with \pm acute angles, branched, glabrous. Leaves sessile, rarely in pseudowhorls, linear-oblong, oblong-lanceolate or oblong-elliptic, $51-79 \mathrm{~mm}$ long, 8-31 mm wide, with a few scattered hairs when young but glabrescent, usually entire or slightly dentate. Peduncles $21-31 \mathrm{~mm}$ long, 1-4 in leaf axils, each with 4-5 flowers, glabrescent or hairy with brown-grey hairs; pedicels hairy with long yellow-grey hairs, 1-3 mm long; bract linear, 4-6 mm long, 0.7-1 mm wide, glabrescent or hairy with light brown-grey hairs; bracteole oblong-elliptic, 3-3.5 mm long, 1-1.5 mm wide, with grey hairs outside, glabrous inside. Sepals 
linear or linear-oblong, $1.5-2 \mathrm{~mm}$ long, $0.3-0.5 \mathrm{~mm}$ wide, tomentose outside with grey hairs. Corolla lobes linear-lanceolate, with long spreading grey type $\mathrm{V}$ hairs outside; inferior lobes 7.5-9 mm long, 2.2-2.6 mm wide; connate part of the inferior lobes narrow-oblong, 5.7-6.5 mm long; superior lobes $6.2-6.8 \mathrm{~mm}$ long, $2-2.5 \mathrm{~mm}$ wide; auricle purple, $1.3-1.6 \mathrm{~mm}$ wide; wing veined, 3.8-4.2 mm wide, smaller above auricle; calli 3-7 in each row. Ovary unilocular, with grey spreading hairs, 2.8-3.1 mm long; ovule single, oblong, 1-1.3 mm long, erect, basifixed; indusium glabrous, dark-brown, $0.7-1 \mathrm{~mm}$ long, $1-1.2 \mathrm{~mm}$ diam. Fruit similar to ovary.

RANGE: Port Curtis, Wide Bay and Moreton regions of Queensland, and North and Central Coast regions of New South Wales.

HABITAT: Forests and woodland.

DISCUSSION: This species is possibly close to $D$. stricta, but it can be separated by the long spreading greyish hairs on the outside of the corolla, and also by leaves which are usually entire, longer and wider than those of $D$. stricta and not usually grouped into pseudowhorls although this may sometimes occur.

The specific epithet refers to the usual habitat of this species.

Selected Specimens EXAmined (10/18): New South Wales: Chatsworth to Woodburn, J.H. Maiden \& J.L. Boorman, (NSW 83447); Wellington Mt., J. Wedd, x-1891 (NSW); Bucca Creek, J. Boorman, 11-xii-? (NSW 83444); Wardell, W. Baeuerlen, xi-1893 (NSW 83446); Near Dunwich, R. Perry 456, 28-ix-1947 (CANB); The Plain Green Hills, c. 10 miles $(16 \mathrm{~km}$ ) directly $\mathrm{N}$ of Woolgoolga, D.J. McGillivray 16, 19-iii-1965 (NSW 97503); Booti Booti, H. Johnson, 13-x-1953 (NSW 83437); Bullahdelah, H.M.R. Rupp, ix-1923 (NSW 83438). QUEENSLAND: c. 2 miles $(3.2 \mathrm{~km}) \mathrm{S}$ of Tewantin, P. Baxter \& B. Lebler 1104, 1-x-1968 (CANB); Elimbah, H.S. McKee 9724, 4-xii-1962 (CANB, NSW).

D. loranthifolia F. Muell. ex Benth., Fl. Austral. 4: 115 (1868).

LECTOTYPE: among rocks, Phillips River, Maxwell 1861 (K). IsOLECTOTYPE: $\mathrm{BM}^{\#}$.

D. fasciculata R. Br., Prodr.: 588 (1810).

LECTOTYPE: King George IIIrds Sound, $R$. Brown Dec. 1801 (BM). ISOLECTOTYPE: $\mathrm{K}^{*}$.

D. glabrescens Benth., Fl. Austral. 4: 119 (1868).

LECTOTYPE: Drummond 4th coll. 194 (K). IsOLECTOTYPE: BM\#.

D. subverticillata De Vriese in Lehm., Pl. Preiss. 1: 403 (1845).

LECTOTYPE: In rupestris collinum Konkoberuphills Kent, Preiss 1510, 19 Nov. 1840 (LD 0497). ISOLECTOTYPE: MEL 1669*.

D. leptoclada Benth., Fl. Austral. 4: 116 (1868).

LECTOTYPE: King Georges Sound, Mueller (K)\#. 
D. trialata De Vriese in Lehm., Pl. Preiss. 1: 401 (1845).

LECTOTYPE: In arenosis umbrosis inter frutices densos sylvae prope urbiculam Perth, Preiss 1444, 6 Aug. 1839 (LD 0498). ISOLECTOTYPES: L 903311 ...202, MEL 516670, $\mathrm{W}^{*}$.

\section{D. obliqua Rajput \& Carolin, sp. nov.}

Caules triangulares. Folia lineari-oblonga ad oblongo-lanceolata integra. Corolla pilis adpressis argenteis obtecta; lobi superiores falcati parte distali unius alae ad auriculam obsoleto. Ovarium obliquum, indusium bilabiatum.

Holotype: Western Australia: 17 miles $(27.2 \mathrm{~km})$ east of Pingelly, R.D. Royce 7601 , 19 Sept. 1962 (PERTH).

Erect multicaulate perennial to $70 \mathrm{~cm}$. Stems triangular with acute angles, glabrous. Leaves sessile, linear to linear-oblong or oblong-lanceolate, very rarely oblong-elliptic, 11-65 mm long, $1.5-21 \mathrm{~mm}$ wide, with a few scattered hairs when young but glabrescent, entire, acute. Peduncles glabrous or with a few small silvery grey hairs, $3.5-5.5 \mathrm{~mm}$ long; bract oblong-elliptic, $1.2-1.6 \mathrm{~mm}$ long, $0.7-1 \mathrm{~mm}$ wide, glabrous; bracteole oblong to narrow-elliptic, $1-1.5 \mathrm{~mm}$ long, 0.3-0.5 mm wide, glabrescent outside. Sepals unequal, 0.4-0.6 mm long, $0.3-0.5 \mathrm{~mm}$ wide, glabrous. Corolla lobes linear-oblong, with silvery to grey appressed type IV hairs outside; inferior lobes $4.5-5.2 \mathrm{~mm}$ long, $1-1.2 \mathrm{~mm}$ wide; connate part of the inferior lobes 3-4 mm long; superior lobes 6-7 mm long, 1-1.2 $\mathrm{mm}$ wide; auricle purple-red, $1-1.4 \mathrm{~mm}$ wide; wing veined, 2.4-3 mm wide, almost obsolete above auricle; calli to 3 in each row. Ovary unilocular, oblique at top, covered with appressed silvery-white to grey short hairs, 1.6-2 mm long; ovule single, oblong, erect or very slightly bent, 1.5-1.9 mm long, basifixed; style glabrous, 3.5-4 mm long; indusium red-brown, 0.7-1 mm long, 0.6-0.9 mm diam.

RANGE: Dale and Darling-Menzies regions of Western Australia.

HABITAT: On sandplains.

DISCUSSION: A well defined species, distinguished by the oblique ovary to which the specific epithet refers.

Selected Specimens Examined (7/14): Western Australia: Congelin, W of Narrogin, G. Heinsohn 129, 24-viii-1967 (PERTH); West Popanyinning, F. Lullfitz L1725, 28-xi1962 (PERTH); Near Narrogin, N.T. Burbidge 2312, 9-ix-1947 (MEL); Dryandra State Forest, Narrogin, E.C. Nelson ANU 16899, 10-xi-1972 (CANB 246999); Kukerin to Kalgan Road, B. Benn, 5-x-1963 (SYD); Drummond 161 (NSW, MEL); 20 miles (32 km) SE of Wickepin, K.M. Allan 136, 4-ii-1969 (PERTH, SYD).

\section{Series Camptospora}

D. epiphylloidea De Vriese in Lehm., Pl. Preiss. 1: 402 (1845).

Lectotype: In Australia occidentali, Preiss 1494 (LD 0488). IsOlectotypes: L $90962 \ldots 71$, MEL 516676, W*.

D. lindleyi De Vriese in Lehm., Pl. Preiss. 1: 402 (1845).

Lectotype: In limosa calculosis sylvarum, York, Preiss 1514, 13 Sept. 1839. (L $90962 \ldots 83$ (second specimen from the right)). De Vriese cited the specimen 
as 'Preiss 1574' in the protologue but subsequently corrected this to 1514 in Lehm., Pl. Preiss. 2: 242 (1848). IsOlECTOTYPES: L 903311...201, MEL $516695, \mathrm{~W}^{*}$.

\section{D. deltoidea Rajput \& Carolin, sp. nov.}

Caules parce ramosi alis duabus uterque $3-4 \mathrm{~mm}$ latis. Folia triangularia oblonga vel elliptica integra basim latitudine caulem aequantes. Flores plerumque in fasciculis axillaribus ad trium dispositi. Pedicellus $2-3 \mathrm{~mm}$ longus. Alae petalorum distincte venosae. Ovarium gibbosum.

Holotype: Western Australia: Mt. Drummond, south west of Ravensthorpe, $K$. Newbey 2697, 13th August 1967 (PERTH).

Multicaulate perennial, to $35 \mathrm{~cm}$. Stems 2-winged, glabrous, sparsely branched; wings 3-4 mm wide. Leaves sessile, \pm triangular to oblong-elliptic, $10-16 \mathrm{~mm}$ long, 6-9 mm wide, with a few scattered hairs when young but glabrescent, entire, as wide as the stem at base. Peduncles $2.2-2.5 \mathrm{~mm}$ long, 1-3 together in the upper axils, each bearing a single flower, covered with appressed grey hairs; bract oblong, $1-1.2 \mathrm{~mm}$ long, c. $0.3 \mathrm{~mm}$ wide, with grey hairs outside, glabrous inside; bracteoles oblong, 0.7-1.1 mm long, c. $0.2 \mathrm{~mm}$ wide, hairy outside. Sepals ovate-elliptic, $0.5-0.7 \mathrm{~mm}$ long, c. $0.2 \mathrm{~mm}$ wide, glabrous. Corolla lobes linear, with appressed grey type IV hairs outside; inferior lobes 6$7 \mathrm{~mm}$ long, $0.7-1 \mathrm{~mm}$ wide; connate part of the inferior lobe $4-4.5 \mathrm{~mm}$ long; superior lobes 7-8 mm long, 1.5-1.7 mm wide; auricle purple, 1-1.2 mm wide; wing distinctly veined, $2.7-3.2 \mathrm{~mm}$ wide; calli to 3 in each row. Ovary unilocular, gibbous, with similar but fewer hairs compared to the petals, 1.7-2 mm long; ovule single, horseshoe-shaped, 1.7-2 mm long, basifixed; style glabrous, 4.7-5.2 mm long; indusium glabrous, brown, c. $1 \mathrm{~mm}$ long, 0.3-0.5 mm diam. Fruit \pm orbicular, 2-3 mm diam., glabrescent, veined.

RANGE: Eastern part of Darling-Menzies region of Western Australia.

HABITAT: In sandy loams.

DISCUSSION: This species is distinguished from others with a gibbous ovary by the short triangular to oblong-elliptic leaves, which are the same width at their base as the broadly winged stem. It is related to $D$. alata Lindl., but it can easily be separated from that species by the closely appressed hairs on the corolla and the distinctly veined wings of the corolla lobes.

The specific epithet refers to the deltoid shape of the leaves.

Selected SPecimens Examined (2/5): Western Australia: Fitzgerald River, c. 70 miles $(112 \mathrm{~km})$ ESE of Ongerup, T.E.H. Aplin, I. Lethbridge \& $R$. Coveny 3258, 8-xi1970 (NSW); $1 / 2$ mile $(0.8 \mathrm{~km})$ E of Elverton Mine, K. Newbey 945, 15-ix-1963 (PERTH).

\section{D. angulata Rajput \& Carolin, sp. nov.}

Caules glabri triangulares sed teretes ad basin. Folia sessilia glabra linearia vel lineari-oblonga $17-29 \mathrm{~mm}$ longa. Pedunculus pedicellusque pilis appressis incanis obtectus. Corolla pilis appressis cinereis extus; alae distincte venosae. Ovarium gibbosum pilis appressis obtectum.

HOLOTYPE: WESTERN AUSTRALIA: NE of Ravensthorpe, Blackall \& Gardner 1854, 22 Sept. 1925 (PERTH). 
Erect multicaulate perennial to $50 \mathrm{~cm}$. Stems triangular but terete at the base, 17-29 mm long, 2-3.5 mm wide, glabrous. Leaves sessile, linear to linearoblong rarely the lower few oblong-lanceolate, $15-30 \mathrm{~mm}$ long, 2-4 mm wide, with a few scattered hairs when young but glabrescent, entire. Peduncles 8-13 mm long, 1-3 together in the upper axils, usually each with 1 or rarely 2-3 flowers, hairy with pale hairs; pedicels $3-5.5 \mathrm{~mm}$ long; bract oblong to narrowelliptic, 1-1.5 mm long, $0.5 \mathrm{~mm}$ wide, hairy outside; bracteole linear-oblong, $1-1.5 \mathrm{~mm}$ long, $0.3-0.5 \mathrm{~mm}$ wide, with pale grey hairs. Sepals obscured by hairs, $0.2-0.4 \mathrm{~mm}$ long, c. $0.1 \mathrm{~mm}$ wide. Corolla lobes linear, with grey appressed type IV hairs outside; inferior lobes $5-5.5 \mathrm{~mm}$ long, 1-1.2 mm wide; connate part of the inferior lobes 4-4.5 mm long; superior lobes 6-7 mm long, 1-1.2 mm wide; auricle purple, $1-1.2 \mathrm{~mm}$ wide; wing distinctly veined, 2.5-2.7 mm wide, only slightly smaller above auricle; calli $0-3$ in each row. Ovary unilocular, gibbous, covered with pale grey appressed hairs, $1.5-1.7 \mathrm{~mm}$ long, $1.7-2 \mathrm{~mm}$ wide; ovule single, horseshoe-shaped, $1.7-2.2 \mathrm{~mm}$ long, basifixed; style glabrous, 2.2-2.7 mm long; indusium glabrous, $0.8-1 \mathrm{~mm}$ long, 0.5-0.7 $\mathrm{mm}$ diam. Fruit broad-ovoid, $2 \mathrm{~mm}$ diam., glabrescent.

RANGE: Austin, Avon, Roe and Eyre regions of Western Australia.

HABITAT: On lateritized sandy soil.

DISCUSSION: This species is close to $D$. sacculata, but it can be easily separated by its triangular stem, and the paler grey hairs on the outside of the corolla. The specific epithet refers to the angular stem.

Selected Specimens Examined (10/31): Western Australia: Wongan Hills, W of Elphin, R.D. Royce 6637, 11-ix-1961 (PERTH); Merredin, 4 miles $(6.4 \mathrm{~km})$ on Narrembeen Road, W.J. Peacock 6087.2 (a), 6-ix-1960 (SYD); Parker's Range, E. Merrall, 1890 (MEL); c. $2 \mathrm{~km} \mathrm{~N}$ of Lake King, R.H. Kuchel 1862, 10-ix-1964 (AD 96531226); $\mathrm{S}$ of Grass Patch, main road from Norseman to Esperance, J.H. Willis, 1-ix1947 (MEL); Stokes Inlet, ca. $75 \mathrm{~km} \mathrm{~W}$ of Esperance, A.E. Orchard 1638, 18-x-1968 (PERTH); Ravensthorpe, Gardner \& Blackall, ix-1925 (PERTH); $40 \mathrm{~km} \mathrm{ENE} \mathrm{of}$ Fitzgerald, c. $30 \mathrm{~km}$ WSW of Ravensthorpe, A.C. Beauglehole ACB 49287, 28-viii-1974 (SYD); 40 miles $(64 \mathrm{~km}) \mathrm{E}$ of Ongerup, at rabbit proof fence, $J$. Peacock 6092-2, 1-ix1960 (SYD); 31 miles $(49.6 \mathrm{~km}) \mathrm{N}$ of Esperance, B.L. Turner 5554, 12-ix-1965 (PERTH).

D. sacculata F. Muell. ex Benth., Fl. Austral. 4: 111 (1868).

LECTOTYPE: Upper Kalgan River, Oldfield (K)\#.

D. mooreana E. Pritzel, Bot. Jahrb. Syst. 35: 579 (1905).

LECTOTYPE: In distr. Irwin australi pr. Watheroo, Pritzel 993, Nov. 1901 (AD 97715446). IsOLECTOTYPES: BM, K, L 903311 ...208, PERTH*.

D. tenuicaulis var. curvula (Krause) Rajput \& Carolin, comb. et stat. nov.

BASIONYM: D. curvula Krause, Pflrch. 54: 197 (1912).

D. heteroptera Rajput \& Carolin, sp. nov.

Caules complanati una costa distincte in quoque latere. Folia linearia. 
Pedunculi 11-36 mm longi. Ala super auriculum lobi superioris obsoleta. Ovarium gibbosum fere glabrum in gibbo. Fructa glabrescentes.

Holotype: Western Australia: near Augusta, A.M. Ashby 3696, 21 Oct. 1970 (PERTH), ISOTYPE: SYD.

Erect multicaulate perennial to $60 \mathrm{~cm}$. Stems flat, sparsely branched, not winged but with a distinct rib on either side, glabrous, internodes often up to $20 \mathrm{~cm}$ long. Leaves sessile, linear, with a few scattered hairs when young but glabrescent, $10-55 \mathrm{~mm}$ long, $1.5-3.7 \mathrm{~mm}$ wide, entire. Peduncles glabrous, usually $1-3$ in each axil each with 2-5 flowers, 11-36 mm long; pedicels $8-10.5 \mathrm{~mm}$ long, glabrous; bract linear-oblong, $3.5-5.2 \mathrm{~mm}$ long, $0.5-1 \mathrm{~mm}$ wide, glabrous; bracteole linear, $1.5-1.7 \mathrm{~mm}$ long, $0.3-0.5 \mathrm{~mm}$ wide, glabrous. Sepals glabrous, linear, c. $0.5 \mathrm{~mm}$ long, c. $0.4 \mathrm{~mm}$ wide. Corolla lobes linearlanceolate, with appressed grey type IV hairs outside; inferior lobes $5.5-6.2 \mathrm{~mm}$ long, 1-1.2 mm wide; connate part of the inferior lobe $2.2-2.7 \mathrm{~mm}$ long; superior lobe $5-5.7 \mathrm{~mm}$ long, $1.2-1.6 \mathrm{~mm}$ wide; auricle purple-red, $1.2-1.5 \mathrm{~mm}$ wide; wing distinctly veined, $2.3-2.7 \mathrm{~mm}$ wide, almost obsolete above auricle; calli $0-3$ in each row. Ovary unilocular, gibbous, hairy except for the gibbosity which is almost or quite glabrous, $1.2-1.5 \mathrm{~mm}$ long, $1.7-2 \mathrm{~mm}$ wide; ovule single, horseshoe-shaped, $1.5-1.7 \mathrm{~mm}$ long, basifixed; style glabrous, 2-3 mm long; indusium dark brown, swollen towards the base, $0.5-0.7 \mathrm{~mm}$ long, $1.2-1.5 \mathrm{~mm}$ diam. Fruit orbicular, $2-3.5 \mathrm{~mm}$ in diam., glabrescent.

RANGE: Irwin and western parts of Darling-Menzies and Warren regions of Western Australia.

HABITAT: In swamps and marshy places.

Discussion: This species is distinguished from the other species with a gibbous ovary by its sparsely branched stems with internodes $6-20 \mathrm{~cm}$ long; its linear leaves; and the almost glabrous gibbosity of the ovary. The specific epithet refers to the different sizes of the wings on the superior corolla lobes.

Selected Specimens Examined (5/9): Western Australia: 30 miles $(48 \mathrm{~km}) \mathrm{W}$ of Nannup, A.R. Fairall 826, 18-x-1962 (PERTH); Cowaramup, R.D. Royce 2832, 15-x-1948 (PERTH); Scott River, Susan Paust 240, 8-ix-1971 (PERTH); Wanra Glen, E of Karridale, R.D. Royce 2431, 28-x-1947 (PERTH); S of Blackwood River, R.D. Royce 2948, 24-X-1948 (PERTH).

\section{Sect. Linschotenia}

\section{D. atriplicina Gardner ex Rajput \& Carolin, sp. nov.}

Plantae erectae vel adscendentes lignosae tomentosae. Caules teretes. Folia ovata vel obovato-elliptica $17-65 \mathrm{~mm}$ longa utrinque tomentosa. Flores in racemis scapiformis $60-90 \mathrm{~cm}$ longis tomentosis dispositi. Bracteae lineares tomentosae 6-8 mm longae. Sepala 5-7 mm longa. Auricules duae in quoque lobus superior corollae dispositae.

Holotype: Western Australia: 4 miles $(6.4 \mathrm{~km}) \mathrm{N}$ of well no. 12, Canning Stock Route, H.M. Wilson 6, 5-x-1942 (PERTH).

Ascending closely greyish or pale brownish tomentose subshrub probably to $60 \mathrm{~cm}$. Stems terete. Leaves with petioles to $11 \mathrm{~mm}$ long, ovate or obovateelliptic, $17-65 \mathrm{~mm}$ long, $7-28 \mathrm{~mm}$ wide, tomentose on both surfaces, entire or dentate. Flowers in scapiform racemes; scape $6-9 \mathrm{~cm}$ long, pedicels $1-1.5 \mathrm{~mm}$ 
long, with \pm plumose hairs; bract linear, 6-8 mm long; bracteoles 3-4 together, linear, 5-8 mm long. Sepals linear, 5-7 mm long, with plumose hairs. Corolla lobes oblong to lanceolate, with spreading pale grey to pale brown type II hairs outside; inferior lobes oblong, 3.5-4.5 mm long, 1-1.2 mm wide; connate part of inferior lobes $3.5-4 \mathrm{~mm}$ long; superior lobes oblong-lanceolate, $5-5.5 \mathrm{~mm}$ long; auricles brownish, two on each superior lobe, $1.5-2 \mathrm{~mm}$ wide; wing scarcely veined, c. $0.5 \mathrm{~mm}$ wide; calli obsolete. Ovary 1-locular, $2.5-3.2 \mathrm{~mm}$ long, hairy as corolla; ovule single, oblong, c. $2 \mathrm{~mm}$ long, erect, basifixed; style 4-4.5 mm long, glabrous; indusium c. $1 \mathrm{~mm}$ diam, glabrous. Fruit unknown.

RANGE: Canning, Keartland and Mueller regions of Western Australia.

HABiтAT: Sand dunes.

DISCUSSION: This species differs from all others in this Section in the grouping of 3-4 bracteoles together. The superficial similarity to Atriplex species, because of the close grey indumentum and the leaf shape, is very characteristic. Although there are few collections, it appears to be very widespread but constant in its characters. The name was suggested by C.A. Gardner on collections in PERTH.

SPECIMENS EXAmined: WeStern Australia: E of Gregory Range on rabbit-proof fence, R.D. Royce 1980, 22-v-1947 (PERTH); 19 miles (30.4 km) NNE of Jupiter Well, Gibson Desert, A.S. George 9066, 28-vii-1968 (PERTH).

D. cinerea Ewart \& Davies, Fl. N. Terr.: 269 (1917).

LECTOTYPE: NW by N of Meyers Hill Macdonnell Ranges, G.F. Hill 212, 1-61911 (MEL 16669)\#.

D. conospermoides W.V. Fitzg., Journ. Roy. Soc. W. Austral. 3: 216 (1918).

LECTOTYPE: Dillons Springs, W.V. Fitzgerald, x-1906 (NSW 83460). ISOLECTOTYPES: NSW 76561, BM*. It is likely that Fitzgerald used at least both specimens in NSW when casting his diagnosis.

D. candicans F. Muell., Fragm. 10: 86 (1876).

LECTOTYPE: Inter montes Alfred-Maries et Rawlinsons Ranges, E. Giles (MEL 516671). ISOLECTOTYPES: K, NSW*.

D. stenostachya E. Pritzel, Bot. Jahrb. Syst. 35: 577 (1905).

LECTOTYPE: in distr. Coolgardie pr. Southern Cross, Pritzel 864 (K). ISOLECTOTYPES: BM, L $903311 \ldots 207, \mathrm{~W}^{*}$.

\section{D. krauseana Rajput \& Carolin, sp. nov.}

Frutex caulibus teretibus tomento brevi flavide-albicanti obtectibus. Folia sessilis spathulata dentata in pagina dorsali glabrescentia. Flores in racemis dispositi. Corolla pilis flavide-brunnis dendriticis multiramosis extus callisque obsoleti. Labia indusii plus minusve pubescens.

Holotype: Western Australia: Ajana, C.A. Gardner, 27-x-1926 (PERTH). 
Erect, branched hairy shrub to c. $60 \mathrm{~cm}$ high. Stem terete, closely tomentose with yellowish grey hairs. Leaves sessile, obovate, 11-28 mm long, 3-15 mm wide, light grey to brownish grey tomentose on both surfaces when young but glabrescent on the upper surface, deeply dentate distally. Flowers arranged in a loose raceme to $20 \mathrm{~cm}$ long; pedicels tomentose, $1-4 \mathrm{~mm}$ long; bracts oblong-elliptic, $1-3 \mathrm{~mm}$ long, to $0.7 \mathrm{~mm}$ wide, tomentose outside; bracteole linear, to $2 \mathrm{~mm}$ long, tomentose as bract. Sepals attached halfway up ovary, $0.5-0.7 \mathrm{~mm}$ long, usually with plumose silky hairs towards top. Corolla lobes tomentose with much-branched spreading grey type I hairs outside; inferior lobes linear-oblong, 5-6 $\mathrm{mm}$ long, to $1 \mathrm{~mm}$ wide; connate part of inferior lobes 2.5-4 mm long; superior lobes oblong-lanceolate, 6-7 mm long, to $1 \mathrm{~mm}$ wide; connate part of superior lobe $1-1.5 \mathrm{~mm}$ long; auricle purple-red, to $1.5 \mathrm{~mm}$ wide; wing veined, $2-3 \mathrm{~mm}$ wide, short above the auricle; calli obsolete. Ovary unilocular, densely tomentose as corolla, to $2 \mathrm{~mm}$ long; ovule solitary, linear-oblong, basifixed, to $1 \mathrm{~mm}$ long; style glabrous, $3-3.5 \mathrm{~mm}$ long; indusium red-brown, glabrous except for the hairy lips, c. $0.5 \mathrm{~mm}$ diam. Fruit ovoid, similar to ovary.

RANGE: Irwin region of Western Australia.

HABITAT: Sandy heaths.

Chromosome Number: $n=9$, Peacock 60846.1 and 60853.2 (SYD), as $D$. stenophylla.

DISCUSSION: This species is related to D. spicigera but can be distinguished by its obovate deeply dentate leaves, the absence of calli, and the much-branched dendritic grey hairs on the outside of the corolla. 1912.

The species is named in honour of K. Krause who revised the genus in

Selected Specimens Examined (2/9): Western Australia: East Yuna Reserve, A.C. Burns 2, 5-vi-1966 (PERTH); Geraldton to Mullewa road, c. $32 \mathrm{~km}$ from Geraldton, Jean Galbraith WA170, 20-vii-1964 (MEL).

D linschotenii F. Muell., Fragm. 6: 28 (1867).

This name is superfluous since Linschotenia discolor De Vriese (= Dampiera discolor (De Vriese) Benth.) is cited as a synonym.

\section{D. ramosa Rajput \& Carolin, sp. nov.}

Herbae scapiformes perennes villosae ad basim. Folia basalia petiolata obovata usque spathulata $2.5-9 \mathrm{~cm}$ longa $12-41 \mathrm{~mm}$ lata tomento flavida in pagine inferiore sed glabra in pagine superiore. Flores in thyrsis $2.2-4.5 \mathrm{~cm}$ longis. Bracteae bracteolaeque lineari-oblongae. Sepala $2-4.5 \mathrm{~mm}$ longa. Petala flavide tomentosa extus pilis brevis dendriticis alisque 1-1.7 mm latis. Ovarium loculo una.

Holotype: Western Australia: 3 miles $(4.8 \mathrm{~km}) \mathrm{NE}$ of Beegull Rock Hole, Laverton-Warburton road, A.S. George 8122, 29-ix-1966 (PERTH). IsOTYPE: SYD.

Erect perennial herb to $40 \mathrm{~cm}$ with a thick tufted densely villous rootstock. Leaves mostly basal, with a petiole $25-58 \mathrm{~mm}$ long, obovate to spathulate, $2.5-9 \mathrm{~cm}$ long, $12-41 \mathrm{~mm}$ wide, very pale yellowish tomentose below, glabrescent above, entire or dentate. Flowers in leafless racemes to $4.5 \mathrm{~cm}$ long 
often branched at the base and on scapes to $45 \mathrm{~cm}$; pedicels $2-3 \mathrm{~mm}$ long, tomentose or glabrescent; bracts linear-oblong, 3-9 mm long, acute, mostly glabrescent; bracteoles 2, linear-oblong, 2-7 mm long, mostly glabrescent. Sepals linear, hairy, $2-4.5 \mathrm{~mm}$ long, attached halfway up ovary. Corolla lobes oblong to lanceolate, with spreading yellowish type I hairs outside; inferior lobes $3-5 \mathrm{~cm}$ long; connate part of inferior lobes $1.5-2.5 \mathrm{~mm}$ long; superior lobes \pm falcate, 3-5 mm long; auricle purplish, 1-2 $\mathrm{mm}$ wide; wing mauvish, scarcely veined, 1-1.5 mm wide, shorter above auricle; calli obsolete. Ovary 1-locular, 2-3 mm long, slightly oblique, hairy as corolla; ovule single, oblong, broader towards apex, c. $2 \mathrm{~mm}$ long, usually laterally attached a little above the base; style 5-6 mm long, glabrous; indusium c. $1 \mathrm{~mm}$ diam., glabrous. Fruit ovoid, 4-5 mm long.

RANGE: Helms region of Western Australia.

HABITAT: Sand dunes.

DISCUSSION: This species is superficially rather like $D$. eriocephala but the flowers are arranged in a loose raceme and the hairs are pale yellow. The specific epithet refers to the branching of the scape and the inflorescence.

SPecimens Examined: Western Australia: 30 miles $(48 \mathrm{~km}) \mathrm{W}$ of Neale Junction Great Victoria Desert, A.S. George 8401, 10-x-1966 (PERTH); between Tjidileburra Rock Hole and Serpentine Lakes, D.E. Symon 12672, 26-viii-1980 (ADW 55188), SYD).

D. eriocephala De Vriese, Nat. Verh. Maats. Wet. Haarlem 2: 118 (1854).

LECTOTYPE: Drummond 397 (K). ISOLECTOTYPE: MEL.

D. eriocephala var. concolor F. Muell. ex Benth., Fl. Austral. 4: 120 (1868).

LECTOTYPE: Drummond no. 162 (MEL 16712)*.

D. humilis F. Muell. ex E. Pritzel, Bot. Jahrb. Syst. 35: 582 (1905).

NEOTYPE: Parkers Range, E. Mirral, 1890 (MEL 42151)*. There is no certainty that Pritzel used this specimen, at present in MEL, to cast his diagnosis of this species although it appears to be the same collection as the one he cites. It agrees well with the description.

\section{Acknowledgements}

To Belinda Pellow for preparing some of the figures; to the Director of the Royal Botanic Gardens, Sydney, for the opportunity to use the computer located there; and to Peter Weston and Peter Wilson, both of the National Herbarium of N.S.W., for assistance in running the PAUP package. This work was done whilst one of us (MTMR) held a post-graduate scholarship from the University of Sydney and contains some material submitted for a Ph.D. at that university.

\section{References}

Anderson, R.H. (1961) Introduction to Flora series. Contr. New South Wales Natl Herb., Flora series nos. 1-18.

Beard, J.S. (1980) A new phytogeographic map of Western Australia. W. Austral. Herb. Res. Notes 3: 37-58. 
Beauglehole, C. (1980) 'Victorian vascular plant check lists' (Western Victorian Field Nat. Clubs Assoc.: Portland).

Bentham, G. (1868) 'Flora Australiensis'. Vol. 4 (L. Reeve: London).

Carolin, R.C. (1959) Floral structure and anatomy in the family Goodeniaceae Dumort. Proc. Linn. Soc. New South Wales 84: 252-255.

Carolin, R.C. (1967) The concept of the inflorescence in the order Campanulales. Proc. Linn. Soc. New South Wales 92: 7-26.

Carolin, R.C. (1970) The trichomes of the Goodeniaceae. Proc. Linn. Soc. New South Wales 96: 8-22.

Carolin, R.C. (1977) The systematic relationships of Brunonia. Brunonia 1: 9-29.

Carolin, R.C. (1985) Mitchells Theorem. Austral. Syst. Bot. Soc. Newsletter 40: 1-9.

Carolin, R.C. (1987). A review of the family Portulacaceae. Austral. J. Bot. 35: 383-412.

Chippendale, G.M. (1972) Check list of Northern Territory plants. Proc. Linn. Soc. New South Wales 96: 207-267.

Crisp, M.D. (1983) Plantae Preissianae types in Lund. Austral. Syst. Bot. Soc. Newsletter 36: 4-6.

Fiala, K.L., \& Sokal, R.R. (1985) Factors determining the accuracy of cladogram estimation: Evaluation using computer simulation. Evolution 39: 609-622.

Jessop, J.P. \& Toelken, H.R. (1986) 'Flora of South Australia'. Edn 4, vol. 1 (Govt. Printer: Adelaide).

Johnson, L.A.S., \& Briggs, B.G. (1985) Myrtales and Myrtaceae - A phylogenetic analysis. Ann. Missouri Bot. Gard. 71: 700-756.

Krause, K. (1912) 'Das Pflanzenreich' vol. 54, Goodeniaceae und Brunoniaceae (Engelmann: Berlin).

MacLean, R. (ed.) (1886) 'The new atlas of Australia' (J. Sands: Sydney).

Maddison, W.P., Donohue, M.J., \& Maddison, D.R. (1984) Outgroup analysis and parsimony. Syst. Zool. 33: 97-103.

Nelson, G. (1978) Onotogeny, phylogeny, paleontology and the biogenetic law. Syst. Zool. 27: 324-345.

Peacock, W.J. (1963) Chromosome numbers and cytoevolution in the Goodeniaceae. Proc. Linn. Soc. New South Wales 88: 8-27.

Pritzel, E. (1905) Fragmenta Phytogeographica Australiae occidentalis. Bot. Jahrb. Syst. 35: 56-662.

Rajput, T., \& Carolin, R.C. (1984) Phyllotaxis and stem vascularization of Dampiera R. Br. (Goodeniaceae). Proc. Linn. Soc. New South Wales 107: 479-485.

Swofford, D. (1984) 'PAUP-Phylogenetic Analysis using parsimony'. (The author, Illinois Natural History Survey: Champagne.)

\section{Appendix 1}

\section{Summary of characters used in phylogenetic analysis}

1. Habit: sub-shrub; rosette

2. Habit: sub-shrub; multicaulate

3-6. Hair types on corolla (see Fig. 2)

7. Phyllotaxis: $2 / 5$ or less; $1 / 3$ or $1 / 2$

8-10. Stem section: terete; 5-ribbed; 3-angled; flat

11. Leaves: flat; revolute (recurved)

12. Leaves: cauline; basal

13. Leaves: not in pseudowhorls; tending to be in pseudowhorls

14. Leaves: all \pm same size; reduced in inflorescence region

15. Leaves: petiolate; sessile

16-18. Hairs on leaves: glabrous; hairy on both surfaces; glabrescent above; glabrescent above and below

19-21. Inflorescence (see Fig. 1)

22. Sepals: present or absent; replaced or surmounted by tuft of hairs

23. Corolla: large; small 
24. Ovary: 2-locular; 1-locular

25. Ovary: straight; gibbous

26-27. Ovule shape: straight; bent; horseshoe-shaped

\section{Appendix 2}

\section{Character state codes of terminal taxa used in cladistic analysis}

$\begin{array}{ll}\text { ALAT } & 010111111100001111000001111 \\ \text { ANGU } & 010110111000001111000001111 \\ \text { CARI } & 010110110000011111000001111 \\ \text { CORO } & 010110111000001111000001111 \\ \text { DECU } & 010110111000001111000000000 \\ \text { FASC } & 010111111000101111000001000 \\ \text { FUSC } & 010111111000101110000001000 \\ \text { LEPT } & 010110111000001111000001000 \\ \text { OBLI } & 010110111000001111000001100 \\ \text { PARV } & 010110110000001111000001000 \\ \text { STRI } & 010111111000101111000001000 \\ \text { TRIL } & 010111111000001111000001000 \\ \text { TRIG } & 010110111000001111000000000 \\ \text { ALTI } & 010000010000001100000001010 \\ \text { ADPR } & 011000010000001111000001000 \\ \text { ERIA } & 011000010010001110000001000 \\ \text { HAEM } & 011000010000001100000001000 \\ \text { HEDE } & 010000010000000100000001000 \\ \text { INCA } & 010000010000001100000001010 \\ \text { LAVA } & 011000010010001110000001000 \\ \text { LANC } & 011000010000001110000001000 \\ \text { LINE } & 011000010000001111000001000 \\ \text { MARI } & 011000010000001100000001000 \\ \text { OLIG } & 010000010000001111000001000 \\ \text { ORCH } & 010100010000001100000001000 \\ \text { PURP } & 010000010000001110000001000 \\ \text { SCAE } & 010100010000001111000001000 \\ \text { STEP } & 011000010000001100000001000 \\ \text { TENU } & 011000010000001111000001000 \\ \text { ATRI } & 001000000000010100110001000 \\ \text { CAND } & 000000000000010110110011000 \\ \text { CINE } & 000000000000010100110011000 \\ \text { DISC } & 000000000000010110110001000 \\ \text { KRAU } & 000000000000010100110001010 \\ \text { RAMO } & 100000000001010110100001000 \\ \text { STES } & 000000000000011100110101010 \\ \text { TERE } & 000010000000011100110001000 \\ \text { DENT } & 111000000001011111110101000 \\ \text { ERIO } & 111000000001010110101101010 \\ \text { PLUM } & 011000000001011110101101000 \\ \text { WELL } & 111000000001010111001101000 \\ \text { DIVE } & 019999010000001000000001000\end{array}$

Manuscript received 2 June 1986

Manuscript accepted 19 June 1987 